\title{
LANTHANIDE TETRAD EFFECT IN LIMESTONE: A TOOL TO ENVIRONMENT ANALYSIS OF THE RUTEH FORMATION, NW IRAN
}

\author{
Ali ABEDINI ${ }^{1) *}$, Mansour REZAEI AZIZI ${ }^{1)}$ and Ali Asghar CALAGARI ${ }^{2)}$ \\ 1) Department of Geology, Faculty of Sciences, Urmia University, 5756151818, Urmia, Iran \\ 2) Department of Earth Sciences, Faculty of Natural Sciences, University of Tabriz, 5166616471, Tabriz, Iran \\ *Corresponding author's e-mail: abedini2020@yahoo.com and a.abedini@urmia.ac.ir
}

\begin{tabular}{l} 
ARTICLE INFO \\
\hline Article history: \\
Received 24 May 2018 \\
Accepted 13 July 2018 \\
Available online 31 July 2018
\end{tabular}

\section{Keywords:}

REE

Tetrad effect

Limestone

Chemical environment analysis Iran

\begin{abstract}
Exhibition of lanthanide tetrad effect in PAAS-normalized REE patterns, and non-CHARAC (non-CHArge-RAdius Control) behavior of $\mathrm{Y} / \mathrm{Ho}$ and $\mathrm{Zr} / \mathrm{Hf}$ in limestone of the Ruteh Formation, Kanigorgeh district (NW Iran), were studied in order to understand the reasons of occurrence of lanthanides tetrad effects. The computed values show that the third and fourth tetrads can be used as a good and powerful geochemical tool for investigation of physicochemical conditions of the depositional environment of the limestones. Here, a new mathematical-based method using polar coordination system for tetrad effect values $\left(\mathrm{T}_{\mathrm{p}}\right)$ was used to evaluate under studying limestone. The correlation between $T_{p}$ and some geochemical parameters revealed that the limestone was likely deposited under two different conditions. The obtained results indicated that paleo-redox conditions, adsorption and scavenging by kaolinite and metallic oxides, degree of detrital input, diagenesis intensity, and complexation by polycarbonate ligands are likely the main mechanisms for occurrence of tetrad effect phenomenon in REE distribution patterns in the limestone. This means that tetrad effect phenomenon in REE distribution patterns of limestone can be applied as a good geochemical indicator to evaluate the deposition conditions in limestones.
\end{abstract}

\section{INTRODUCTION}

Investigation of rare earth elements (REE) behavior and their normalized distribution patterns during geochemical processes provide valuable information about carbonate sediments and paleoconditions of depositional environments (Sherrell et al., 1999; Madhavaraju and Ramasamy, 1999; Webb and Kamber, 2000; Armstrong-Altrin et al., 2003; Madhavaraju et al., 2004; Madhavaraju and Lee, 2009; Nagarajan et al., 2011; Madhavaraju and Gonzalez-Leon, 2012; Qiu et al., 2013; Abedini and Calagari, 2015). The REE distribution patterns in seawaters and marine sediments are generally controlled by many factors such as terrestrial material due to weathering, hydrothermal activities, scavenging, oxygen fugacity, proximity to source lithologies, deposition due to biogenic conditions, and diagenesis (Murphy and Dymond, 1984; Liu et al., 1988; Murray et al., 1991; Greaves et al., 1999; Madhavaraju et al., 2010, 2016, 2017, 2018).

Many investigations have been revealed that normalized REE distribution diagrams present the smooth curves due to lanthanides contractions, elimination of the effect of Oddo-Harkins rule (Cantrell and Byrne, 1987), and CHARAC (CHArge RAdius Control) behavior of REE in the geochemical processes (Lottermoser, 1992 and references therein; Bau, 1996). Despite their similar geochemical and CHARAC behavior, these elements show many irregular curves in their normalized distribution patterns have been reported from various depositional environments. This is related to non-CHARAC behaviors of REE such as lanthanides tetrad effect (Censi et al., 2007; Yasnygina and Rasskazov, 2008; Peretyazhko and Savina, 2010; Feng et al., 2011; Nardi et al., 2012; Cao et al., 2013; Lee et al., 2013; Abedini et al., 2017; Rezaei Azizi et al., 2017; Abedini et al., 2018). This phenomenon for the first time, labeled as 'tetrad effect', 'zigzag', 'kinked', and/or 'double-double' (Lee et al., 1994; Kawabe, 1995), reflects a unique characteristic of normalized REE distribution patterns which was reported for the first time in the aqueous extraction of rare earth elements studies in natural materials (Fidelis and Siekierski, 1966; Peppard et al., 1969).

The tetrad effect in normalized REE distribution patterns comprise of four groups in the REE which reflects cusps of one-fourth, half, three-fourth, and fully filled $4 f$ orbital of rare earth elements (Jahn et al., 2001). These four groups are labeled as first (LaCe-Pr-Nd), second (Pm-Sm-Eu-Gd), third (Gd-TbDy-Ho), and fourth (Er-Tm-Yb-Lu) tetrads. Gd is 

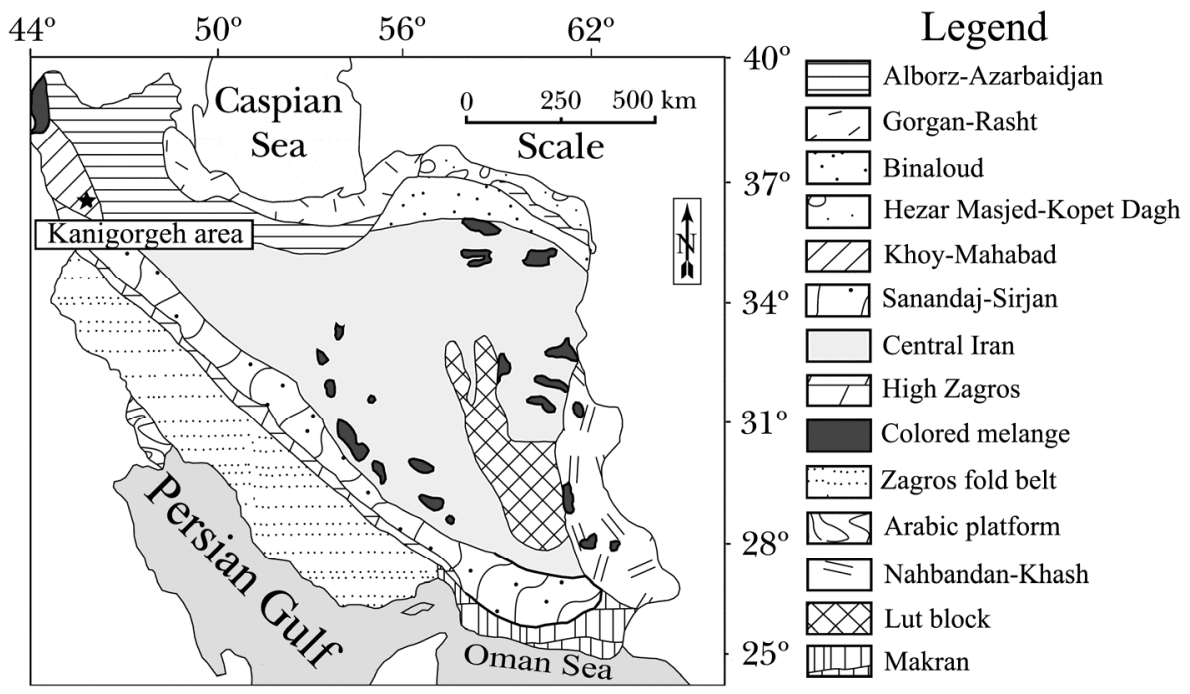

Fig. 1 The simplified structural zones of Iran (Nabavi, 1976). The location of the Kanigorgeh district is also shown.

a common rare earth element which belongs to the second and third tetrads. Despite the occurrence of the tetrad effect phenomenon in many different deposits and lithologies, the presence and reason for this phenomenon is not accepted by some researchers (Yurimoto et al., 1990; McLennan, 1994). Recently, many studies have been conducted to find out mechanism(s) for tetrad effect in a wide range of environments. The results indicate that theory of the variation of the nephelauxetic ratio (Jorgensen, 1970), the spin energy of coupling (Nugent, 1970), electron structure (Masuda et al., 1994), and changes in the GFE (Gibbs free energy) (Kawabe et al., 1999) are the main factors controlling the occurrence of this phenomenon.

Worldwide studies of tetrad effect phenomenon in various lithologies and environments have revealed that normalized REE distribution patterns display convex (M-like), concave (W-like) and/or combination of these two forms. Convex shapes (M-like) in the normalized REE patterns are indicative of igneous and related systems such as hydrothermal activities, alteration and evolution processes (Irber, 1999; Monecke et al., 2007; Nardi et al., 2012; Cao et al., 2013; Lv et al., 2018; Yang et al., 2018). In contrast, concave shapes (W-like) are mostly observed in low-temperature deposits such as marine sediments, limestones, cherts, phosphatic shales, and underground waters (Masuda et al., 1987; Akagi et al., 2004; Rossi et al., 2011; Feng et al., 2014; Abedini et al., 2017). Another form of tetrad effect is known as co-existence of both convex and concave tetrad effect shapes in the same normalized REE distribution patterns such as Tono uranium deposit in Japan, volcanic glasses, ferromanganese nodules and Terra Rossa in China, porphyric rocks in Transbaikalia, cryolites in Pitinga of Brazil, fluorite deposit, phosphatic shales, and titanium-rich bauxites in Iran (Takahashi et al., 2002; Minuzzi et al., 2008; Peretyazhko and Savina, 2010; Feng et al., 2011; Rezaei Azizi et al., 2017; Abedini et al., 2017; Abedini et al., 2018).

The Kanigorgeh district as a mining pit for bauxite deposit is a part of Ruteh Formation, NW Iran. In this district, a Ti-rich bauxite horizon of upper Permian age and a Fe-rich bauxite horizon of PermoTriassic age crop out. Both horizons are hosted by a limestone unit of the Ruteh Formation (Abedini and Calagari, 2015). Mineralogy, petrography, major oxides, and trace elements behavior during deposition of the limestone were studied in details by Abedini and Calagari (2015). In this research, we focus on the REE behavior and mechanisms controlling the occurrence of tetrad effect in samples collected from the limestone of the Ruteh Formation in the Kanigorgeh district as an environment tool for investigation of limestone deposition.

\section{GEOLOGICAL BACKGROUND AND PREVIOUS STUDIES}

The Bukan basin comprises mostly of sedimentary sequences from Paleozoic to InfraCambrian, but there exists a stratigraphic hiatus between Silurian to Carboniferous. The early Paleozoic sequence is overlain unconformably by the Permian limestone characterized by the presence of karstic erosional features, layers of volcanic lavas, and bauxitic-lateritic lenses (Kamineni and EfthekharNezad, 1977; Abedini and Calagari, 2013a, 2013b, 2013c). The studied limestone of the Kanigorgeh district is located in $\sim 20 \mathrm{~km}$ northeast of Bukan city, West-Azarbaidjan province, NW Iran. Based on classification of the structural zones of Iran (Nabavi, 1976), this district is a part of the Khoy-Mahabad zone (Fig. 1), which comprises of various lithologies from Lower Permian to Quaternary (Fig. 2). The 


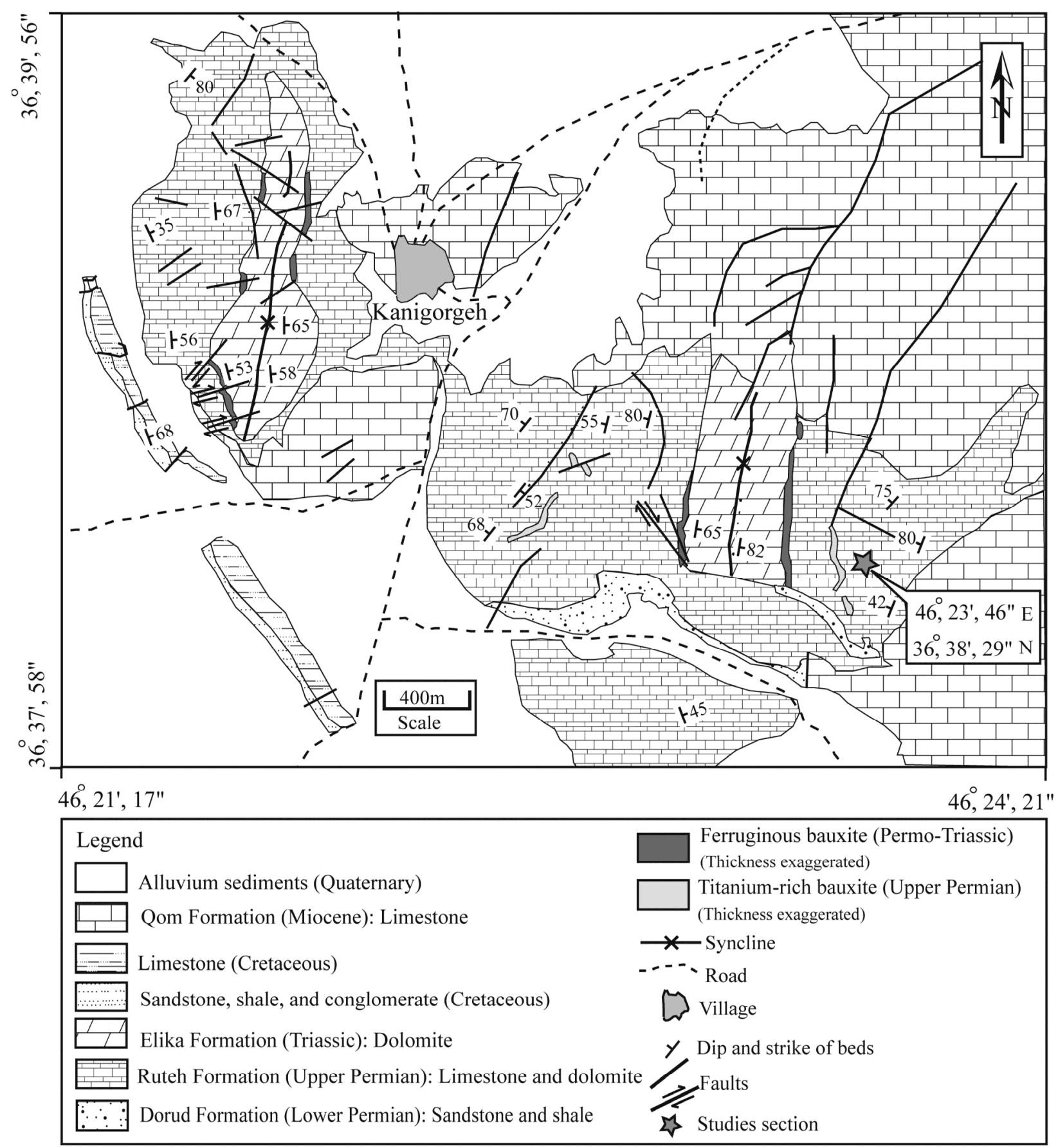

Fig. 2 Geologic map of the Kanigorgeh district on which the lithologic units and position of the studied profile within the Ruteh Formation is shown (after Abedini and Calagari, 2014).

lithologies in this district from the oldest to the youngest are as follow: (1) Sandstone and shale of the Dorud Formation (Lower Permian). The outcrop of this Formation is observed in a small part of the district; (2) limestone and dolomite of the Ruteh Formation (Upper Permian); (3) dolomite of the Elika Formation (Triassic); (4) sandstone, shale, and conglomerate of Cretaceous age; (5) Limestone of Cretaceous age; (6) limestone of the Qom Formation (Miocene); and (7) alluvium sediments (Quaternary).

The Ruteh Formation can be considered as a wide formation in Iran (north of the Middle East ) and in the Kanigorgeh district comprises of carbonate units (Fig. 3) with a thickness of $\sim 450 \mathrm{~m}$, and was likely deposited during the second sedimentary cycle (Abedini and Calagari, 2015). It includes massive to layered limestone and dolomite units with thin interlayers of marl and outcrops of bauxitic-lateritic lenses which the latter is indicative of sedimentation hiatus during the formation of the limestone. This carbonate unit varies in color from grey to dark grey. The depositional environment of the Ruteh Formation is similar to that of modern carbonate sediments (Aghanabati, 2004). 


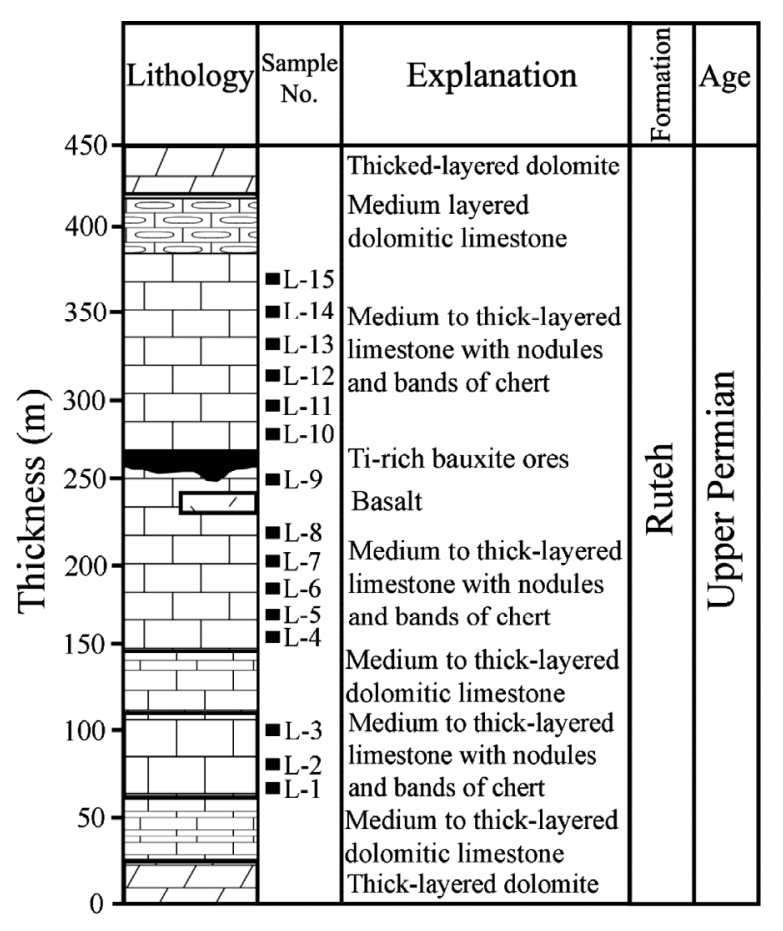

Fig. 3 Lithologic section of the studied profile within the Ruteh Formation in the Kanigorgeh district. Location of the collected samples for geochemical analysis is also shown.

The Ruteh Formation comprises of thick-layered dolomite, medium to thick-layered dolomitic limestone, medium to thick-layered limestone with nodules and bands of chert, and finally mediumlayered dolomitic limestone (Fig. 3). Aghanabati (2004) reported that the limestone of the Ruteh Formation is generally grey and fossiliferous having micritic texture. Based upon the type of fossils (corals, brachiopods, and foraminifera), it was attributed to upper Permian age (Thuringian). On the basis of field observation, silicification, brecciation, and intense shearing, this limestone has characteristically peculiar geological features. Geologic aspects, mineralogy, and petrographic features of the limestone and the enclosed bauxite ores in the Kanigorgeh district were studied in detail by Abedini and Calagari (2013c, 2014, and 2015). Calcite, quartz, plagioclase, kaolinite, and Fe-oxides (hematite) are the most abundant mineral phases in the limestone (Abedini and Calagari, 2015).

\section{METHODS}

A profile across the Ruteh Formation (with $\sim 450 \mathrm{~m}$ thickness) was selected to investigate the geochemical characteristics of the limestone. Fifteen samples (from 20 to $50 \mathrm{~m}$ intervals) were collected from different parts along the profile for chemical analyses. All the weathered materials on the surface of samples were carefully removed. Other contaminations in these samples were removed by washing in distilled water for several times and all samples were dried at a temperature of $40{ }^{\circ} \mathrm{C}$ for 12 hours and then powdered in an appropriate mortar (tungsten carbide). About $0.2 \mathrm{~g}$ of each sample was added to Li-metaborate/lithium tetraborate solution. After cooling these solutions, they dissolved in $100 \mathrm{ml}$ nitric acid $(4 \mathrm{ml})$ /hydrochloric acid $(2 \mathrm{ml})$. These solutions were analyzed for major elements by using inductively coupled plasma atomic emission spectrometry (ICP-AES) method. Meanwhile, trace and rare earth elements were analyzed by using inductively coupled plasma mass spectrometry (ICPMS) method. The loss on ignition (LOI) values of samples was calculated by weight loss of $1 \mathrm{gr}$ of each sample before and after heating at $950{ }^{\circ} \mathrm{C}$ for $90 \mathrm{~min}$. All these analyses were carried out in the laboratories of ALS Chemex, Canada. All the computations and plots were done by using MATLAB R2016b software.

\section{RESULTS}

\subsection{MAJOR AND TREACE ELEMENTS CONCENTRATIONS}

The major and trace elements concentrations of the limestone are listed in Table 1 and the chemical variations are presented in Figure 4. The $\mathrm{SiO}_{2}, \mathrm{Al}_{2} \mathrm{O}_{3}$, and $\mathrm{Fe}_{2} \mathrm{O}_{3}$ contents are within the range of 11.1225.82 wt.\%, 4.15-9.33 wt.\%, and 1.35-2.71 wt.\%, respectively. The concentrations of $\mathrm{CaO}$ varies from 40.61 (in sample L-15) to 42.84 wt.\% (in sample) L-6. The concentration of $\mathrm{MgO}, \mathrm{Na}_{2} \mathrm{O}$, and $\mathrm{K}_{2} \mathrm{O}$ are low and are within the range of $0.74-0.84,0.03-0.27$, and 0.28-0.99 wt.\%, respectively. The $\mathrm{TiO}_{2}, \mathrm{MnO}$, and $\mathrm{P}_{2} \mathrm{O}_{5}$ show low concentration (Table 1). The calculated values for LOI in the limestone vary from of 19.91 to 39.98 wt.\%.

$\mathrm{V}, \mathrm{Cr}$, and $\mathrm{Co}$ in the limestone display variation within the range of 17-41 ppm, 10-100 ppm, and 2.2$6.9 \mathrm{ppm}$, respectively. $\mathrm{Ni}, \mathrm{Rb}, \mathrm{Ba}$, and $\mathrm{Sr}$ show ranges of 18-35 ppm, 2.4-22.1 ppm, 91.5-231.5, and 225.4$285.2 \mathrm{ppm}$, respectively. The variation of $\mathrm{Th}$ and $\mathrm{U}$ are in the range of 6.87-14.06 ppm and 0.31$0.93 \mathrm{ppm}$, respectively. The concentration of $\mathrm{Cu}, \mathrm{Ta}$, $\mathrm{Y}, \mathrm{Zr}, \mathrm{Pb}, \mathrm{Nb}$, and $\mathrm{Hf}$ display ranges of $13-45 \mathrm{ppm}$, 1.6-4.1 ppm, 3.6-8.6 ppm, 32-56 ppm, 5-7 ppm, 1.8$7.9 \mathrm{ppm}$, and 1.1-3.2 ppm, respectively.

\subsection{REE+Y DISTRIBUTION AND GEOCHEMICAL PARAMETERS}

The concentration of REE and Y for the studied limestone samples are listed in Table 2. The concentration of $\sum \mathrm{REE}$ in majority of the samples range from $38.38 \mathrm{ppm}$ to $69.2 \mathrm{ppm}$ but, two samples (L-12 and L-13) show higher values (282.67 ppm and $124.29 \mathrm{ppm}$, respectively). The concentration of $\mathrm{Y}$ varies from 32 to $56 \mathrm{ppm}$. To calculate the $\mathrm{Pr}, \mathrm{Ce}$, and $\mathrm{Eu}$ anomalies the following equations were used (Bau and Dulski, 1996; Webb and Kamber, 2000; Nothdurft et al., 2004):

$\mathrm{Ce} / \mathrm{Ce}^{*}=2 \mathrm{Ce}_{\mathrm{N}} /\left(\mathrm{La}_{\mathrm{N}}+\operatorname{Pr}_{\mathrm{N}}\right)$
$\mathrm{Ee} / \mathrm{Ee}^{*}=\mathrm{Eu}_{\mathrm{N}} /\left[\left(\mathrm{La}_{\mathrm{N}}+\operatorname{Pr}_{\mathrm{N}}\right)^{0.5}\right]$

In these equations $\mathrm{N}$ refers to PAAS (PostArchean Australian Shale, Taylor and McLennan, 
Table 1 Concentration values for major oxides (wt $\%)$ and trace elements $(\mathrm{ppm})$ in the studied limestone.

\begin{tabular}{|c|c|c|c|c|c|c|c|c|c|c|c|c|c|c|c|}
\hline $\begin{array}{l}\text { Sample } \\
\text { No. }\end{array}$ & L-1 & L-2 & L-3 & L-4 & L-5 & L-6 & L-7 & L-8 & L-9 & L-10 & L-11 & L-12 & L-13 & L-14 & L-15 \\
\hline $\mathrm{SiO}_{2}$ & 15.21 & 15.51 & 12.41 & 14.03 & 14.64 & 15.82 & 11.12 & 14.99 & 12.45 & 13.91 & 13.81 & 25.82 & 17.35 & 18.85 & 12.87 \\
\hline $\mathrm{Al}_{2} \mathrm{O}_{3}$ & 6.08 & 6.25 & 4.96 & 5.51 & 5.74 & 5.33 & 4.15 & 5.41 & 4.98 & 4.98 & 5.52 & 9.33 & 6.62 & 7.54 & 5.15 \\
\hline $\mathrm{Fe}_{2} \mathrm{O}_{3}$ & 1.39 & 2.03 & 2.18 & 1.51 & 1.84 & 1.35 & 1.92 & 1.51 & 1.81 & 2.71 & 1.69 & 1.51 & 1.45 & 1.58 & 1.65 \\
\hline $\mathrm{CaO}$ & 42.51 & 42.56 & 42.57 & 42.68 & 42.56 & 42.84 & 42.64 & 42.65 & 42.25 & 42.79 & 42.01 & 41.52 & 41.92 & 41.09 & 40.61 \\
\hline $\mathrm{MgO}$ & 0.79 & 0.79 & 0.84 & 0.78 & 0.79 & 0.82 & 0.79 & 0.74 & 0.79 & 0.82 & 0.78 & 0.78 & 0.77 & 0.74 & 0.78 \\
\hline $\mathrm{Na}_{2} \mathrm{O}$ & 0.03 & 0.06 & 0.09 & 0.04 & 0.06 & 0.03 & 0.04 & 0.03 & 0.07 & 0.07 & 0.11 & 0.17 & 0.14 & 0.22 & 0.27 \\
\hline $\mathrm{K}_{2} \mathrm{O}$ & 0.69 & 0.82 & 0.68 & 0.55 & 0.81 & 0.28 & 0.54 & 0.71 & 0.47 & 0.99 & 0.76 & 0.34 & 0.29 & 0.35 & 0.39 \\
\hline $\mathrm{TiO}_{2}$ & 0.15 & 0.11 & 0.07 & 0.11 & 0.12 & 0.12 & 0.07 & 0.13 & 0.07 & 0.09 & 0.12 & 0.29 & 0.16 & 0.18 & 0.07 \\
\hline $\mathrm{MnO}$ & 0.06 & 0.04 & 0.03 & 0.04 & 0.05 & 0.06 & 0.02 & 0.04 & 0.02 & 0.04 & 0.04 & 0.04 & 0.04 & 0.04 & 0.02 \\
\hline $\mathrm{P}_{2} \mathrm{O}_{5}$ & 0.08 & 0.06 & 0.04 & 0.06 & 0.07 & 0.09 & 0.04 & 0.08 & 0.04 & 0.07 & 0.06 & 0.18 & 0.11 & 0.12 & 0.03 \\
\hline LOI & 30.44 & 31.55 & 37.88 & 34.11 & 32.51 & 32.84 & 39.98 & 31.89 & 38.85 & 34.62 & 33.08 & 19.91 & 31.14 & 29.39 & 37.89 \\
\hline Sum & 99.99 & 99.81 & 99.87 & 99.74 & 99.81 & 99.5 & 99.31 & 99.95 & 99.74 & 99.28 & 99.68 & 99.37 & 99.71 & 99.71 & 99.48 \\
\hline $\mathrm{V}$ & 18 & 17 & 19 & 20 & 18 & 20 & 18 & 18 & 17 & 17 & 18 & 41 & 24 & 35 & 17 \\
\hline $\mathrm{Cr}$ & 20 & 20 & 10 & 14 & 20 & 100 & 10 & 20 & 10 & 10 & 20 & 60 & 70 & 40 & 10 \\
\hline Co & 4.6 & 3.9 & 3.1 & 2.9 & 3.9 & 4.50 & 2.6 & 4.3 & 2.9 & 3.2 & 3.2 & 6.9 & 4.4 & 5 & 2.2 \\
\hline $\mathrm{Ni}$ & 21 & 19 & 18 & 20 & 20 & 25 & 19 & 24 & 18 & 18 & 22 & 35 & 28 & 27 & 18 \\
\hline $\mathrm{Rb}$ & 7.9 & 6.4 & 6.6 & 5.4 & 6.6 & 10.5 & 3.1 & 8.8 & 2.4 & 6.2 & 8.5 & 22.1 & 9.7 & 12.7 & 3.1 \\
\hline $\mathrm{Ba}$ & 231.5 & 195.8 & 124.5 & 161.5 & 204.1 & 220.3 & 109.2 & 224.1 & 100.3 & 160.2 & 215.4 & 156.8 & 170.9 & 123.5 & 91.5 \\
\hline $\mathrm{Sr}$ & 279.2 & 249.3 & 238.7 & 247.2 & 255.2 & 285.2 & 225.4 & 246.1 & 228.2 & 246.3 & 242.9 & 249.5 & 251.4 & 247.2 & 231.5 \\
\hline Th & 6.87 & 7.82 & 7.89 & 7.45 & 7.98 & 7.13 & 6.95 & 7.54 & 8.21 & 7.84 & 9.67 & 11.32 & 9.21 & 12.74 & 14.06 \\
\hline $\mathrm{U}$ & 0.93 & 0.74 & 0.41 & 0.61 & 0.78 & 0.62 & 0.38 & 0.84 & 0.33 & 0.54 & 0.81 & 0.45 & 0.41 & 0.33 & 0.31 \\
\hline $\mathrm{Cu}$ & 25 & 20 & 15 & 20 & 21 & 25 & 14 & 22 & 13 & 15 & 22 & 45 & 27 & 30 & 13 \\
\hline $\mathrm{Ta}$ & 1.8 & 2.1 & 1.9 & 2.1 & 1.7 & 1.9 & 1.8 & 1.7 & 1.6 & 1.8 & 1.9 & 4.1 & 2.4 & 3.6 & 1.7 \\
\hline Y & 4.3 & 4.3 & 4.6 & 4.5 & 4.6 & 3.6 & 4 & 4.5 & 3.9 & 4.3 & 7.6 & 8 & 7.3 & 8.3 & 8.6 \\
\hline $\mathrm{Zr}$ & 34 & 37 & 35 & 38 & 38 & 32 & 37 & 35 & 38 & 38 & 47 & 51 & 45 & 53 & 56 \\
\hline $\mathrm{Pb}$ & 6 & 6 & 6 & 6 & 6 & 5 & 6 & 6 & 6 & 7 & 6 & 5 & 6 & 6 & 6 \\
\hline $\mathrm{Nb}$ & 3.9 & 3.2 & 1.8 & 2.8 & 3.4 & 5.1 & 1.8 & 3.8 & 1.9 & 2.1 & 3.6 & 7.9 & 5.4 & 5.9 & 1.8 \\
\hline $\mathrm{Hf}$ & 1.4 & 1.2 & 1.1 & 1.2 & 1.4 & 1.1 & 1.2 & 1.4 & 1.2 & 1.2 & 2.4 & 2.3 & 2.4 & 2.6 & 3.2 \\
\hline
\end{tabular}



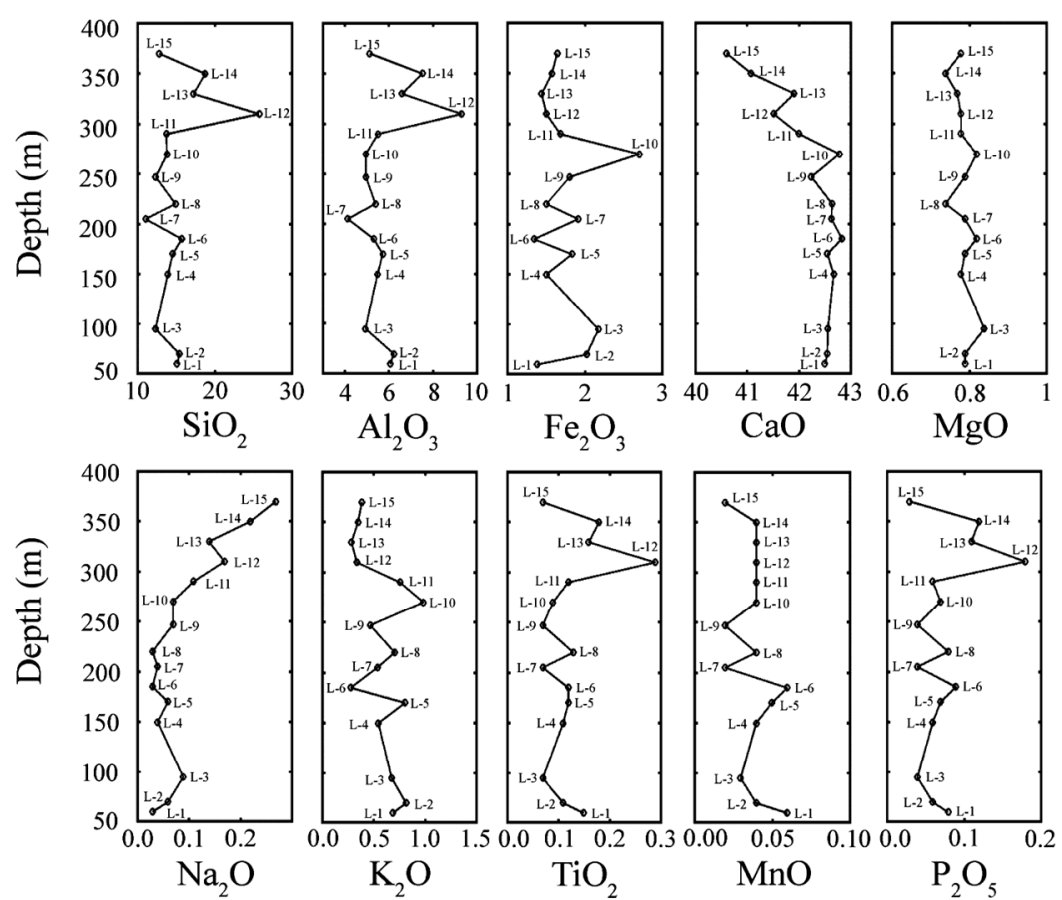

Fig. 4 Distribution pattern for values of oxides (wt $\%)$ in the limestone samples of the studied district.

Table 2 Concentration values for rare earth elements (REE) in the studied limestone.

\begin{tabular}{|c|c|c|c|c|c|c|c|c|c|c|c|c|c|c|}
\hline $\begin{array}{l}\text { Sample } \\
\text { No. }\end{array}$ & L-1 & L-2 & L-3 & L-4 & L-5 & L-6 & L-7 & L-8 & L-9 & L-10 & L-11 & L-12 & L-13 & L-14 \\
\hline $\mathrm{La}$ & 16.01 & 14.02 & 9.88 & 11.82 & 14.51 & 15.41 & 8.88 & 15.54 & 8.27 & 12.09 & 15.11 & 115.11 & 38.36 & 9.85 \\
\hline $\mathrm{Ce}$ & 27.68 & 23.94 & 17.02 & 20.21 & 25.44 & 27.09 & 16.11 & 25.51 & 15.28 & 20.51 & 28.69 & 147.1 & 64.15 & 20.87 \\
\hline $\operatorname{Pr}$ & 2.92 & 2.51 & 1.88 & 2.22 & 2.61 & 2.93 & 1.74 & 2.81 & 1.64 & 2.18 & 2.74 & 2.22 & 2.38 & 1.86 \\
\hline $\mathrm{Nd}$ & 15.64 & 14.29 & 10.89 & 12.13 & 14.54 & 16.43 & 9.81 & 15.29 & 9.24 & 13.14 & 14.98 & 12.51 & 13.28 & 10.34 \\
\hline $\mathrm{Sm}$ & 1.79 & 1.65 & 1.24 & 1.38 & 1.65 & 1.83 & 1.11 & 1.74 & 1.05 & 1.49 & 1.71 & 1.37 & 1.45 & 1.16 \\
\hline $\mathrm{Eu}$ & 0.46 & 0.41 & 0.31 & 0.35 & 0.41 & 0.44 & 0.26 & 0.44 & 0.26 & 0.34 & 0.54 & 0.44 & 0.46 & 0.41 \\
\hline Gd & 1.84 & 1.65 & 1.18 & 1.405 & 1.69 & 1.88 & 1.08 & 1.84 & 1.02 & 1.41 & 1.76 & 1.42 & 1.54 & 1.21 \\
\hline $\mathrm{Tb}$ & 0.16 & 0.13 & 0.12 & 0.15 & 0.13 & 0.22 & 0.12 & 0.15 & 0.14 & 0.12 & 0.16 & 0.21 & 0.21 & 0.18 \\
\hline Dy & 1.16 & 0.99 & 0.69 & 0.88 & 1.02 & 1.16 & 0.64 & 1.11 & 0.63 & 0.81 & 1.08 & 0.91 & 0.98 & 0.75 \\
\hline Ho & 0.21 & 0.18 & 1.16 & 0.17 & 0.21 & 0.24 & 0.63 & 0.19 & 0.39 & 0.17 & 0.21 & 0.21 & 0.23 & 0.18 \\
\hline $\mathrm{Er}$ & 0.64 & 0.56 & 0.41 & 0.49 & 0.59 & 0.67 & 0.38 & 0.61 & 0.34 & 0.46 & 0.61 & 0.52 & 0.53 & 0.41 \\
\hline $\mathrm{Tm}$ & 0.08 & 0.09 & 0.07 & 0.07 & 0.07 & 0.12 & 0.06 & 0.07 & 0.06 & 0.08 & 0.08 & 0.11 & 0.12 & 0.08 \\
\hline $\mathrm{Yb}$ & 0.55 & 0.47 & 0.35 & 0.43 & 0.51 & 0.63 & 0.32 & 0.53 & 0.32 & 0.38 & 0.53 & 0.45 & 0.51 & 0.37 \\
\hline $\mathrm{Lu}$ & 0.06 & 0.08 & 0.08 & 0.06 & 0.06 & 0.12 & 0.06 & 0.06 & 0.05 & 0.09 & 0.06 & 0.09 & 0.09 & 0.06 \\
\hline$\sum \mathrm{REE}$ & 69.2 & 60.97 & 45.28 & 51.765 & 63.44 & 69.17 & 41.2 & 65.89 & 38.69 & 53.27 & 68.26 & 282.67 & 124.29 & 47.73 \\
\hline
\end{tabular}

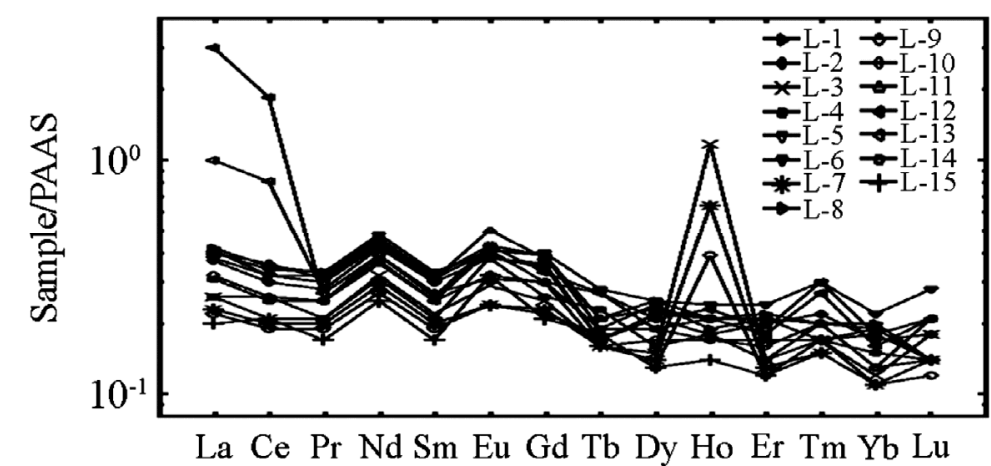

Fig. 5 PAAS-normalized (Taylor and McLennan, 1985) REE distribution curves of the limestone samples in the Kanigorgeh district. 


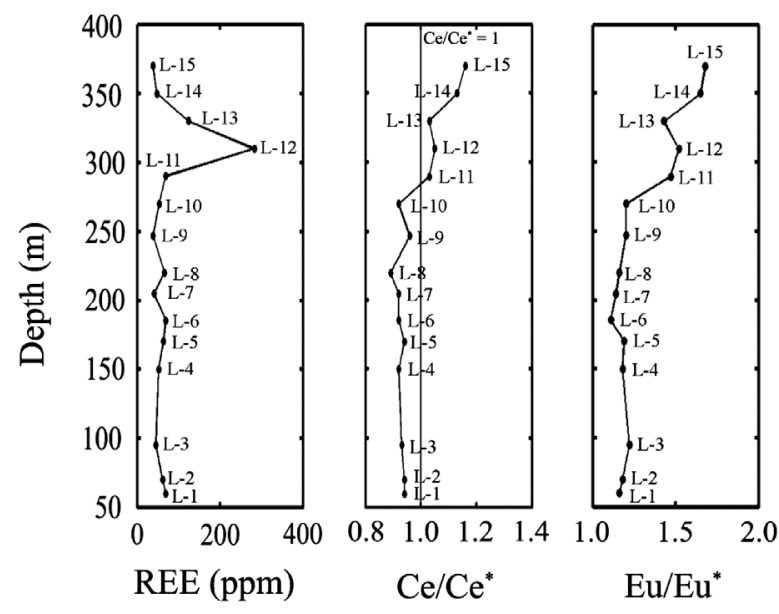

Fig. 6 Distribution pattern for values of REE, Ce-Eu anomalies for the limestone samples of the Ruteh Formation in the Kanigorgeh district.
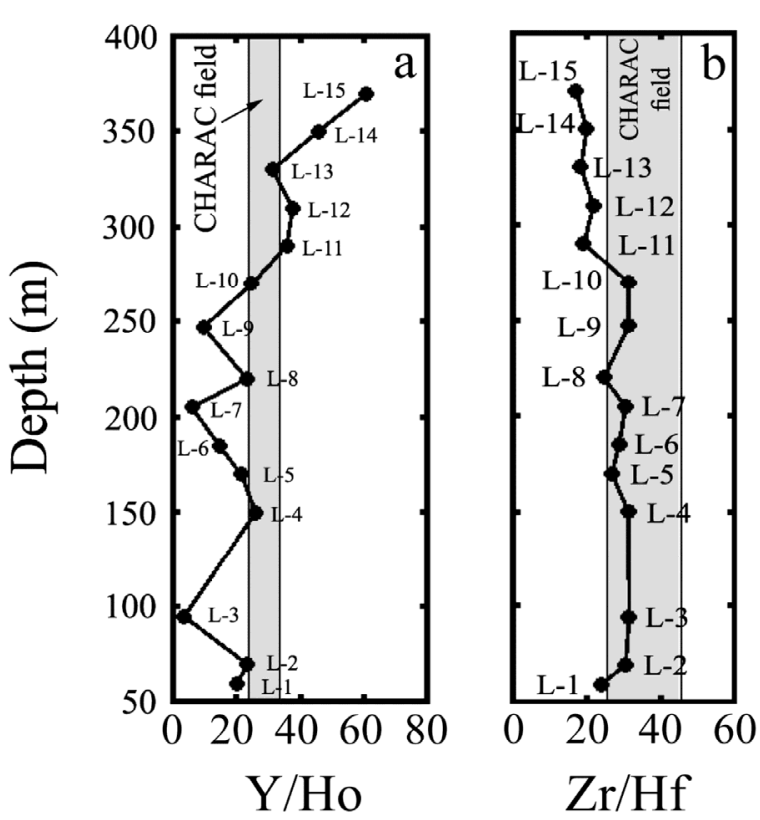

Fig. 8 Distribution pattern for values of (a) Y/Ho and (b) $\mathrm{Zr} / \mathrm{Hf}$ ratios for the limestone samples within the Ruteh Formation in the Kanigorgeh district. The CHARAC field is from Bau (1996).

1985). The Ce anomalies in the limestone samples are within the range of $0.88-1.27$. The Eu anomalies vary from 1.10 to 1.69 . The $\mathrm{Y} / \mathrm{Ho}$ and $\mathrm{Zr} / \mathrm{Hf}$ ratios of the limestone samples display a wide range from 3.97 to 61.43 and 17.5 to 31.81 , respectively.

\section{DISCUSSION}

\subsection{REE DISTRIBUTION AND GEOCHEMICAL PARAMETERS}

The REE signatures in limestones can be affected by some mechanisms such as input of terrigenous particles, $\mathrm{Mn}$ - and/or $\mathrm{Fe}-$ oxides,

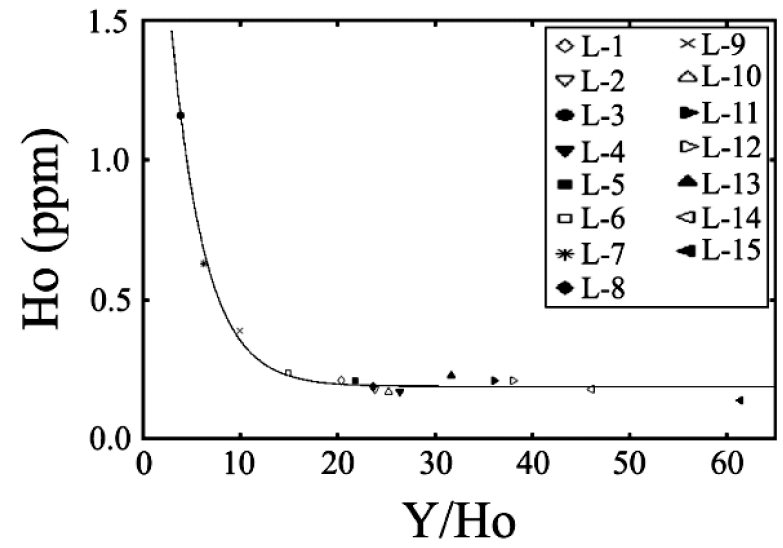

Fig. 7 Bivariate plot of Y/Ho ratios vs. Ho values of the limestone samples within the Ruteh Formation in the Kanigorgeh district.

hydrothermal activities, diagenetic processes, and mineral phases such as phosphates (Elderfield et al., 1990; Bau et al., 1996; Byrne et al., 1996; Bolhar et al., 2004; Tang et al., 2013; Madhavaraju et al., 2016, 2017). The PAAS-normalized (Taylor and McLennan, 1985) REE distribution patterns and chemical variations ( $\sum \mathrm{REE}, \mathrm{Ce}$, and $\mathrm{Eu}$ anomalies) of the limestone samples of the Ruteh Formation are illustrated in Figure 5 and Figure 6, respectively.

As shown in Figure 5, the PAAS-normalized REE distribution pattern of the studied limestones is characterized by remarkable tetrad effect phenomenon (zigzag pattern). Meanwhile, the Ce and Eu anomalies and $\sum$ REE of the limestone display a wide variation from depths of $290 \mathrm{~m}$ (sample L-11) to $370 \mathrm{~m}$ (sample L-15) in the Ruteh Formation (Fig. 6).

Geochemically trivalent pairs such as $\mathrm{Y}$ and Ho represent similar behavior during geochemical processes in various geological environments such as seawater column and magmatic/hydrothermal systems (Shannon, 1976; Gadd et al., 2016). Moreover, fraction between these isovalent pairs due to different surface complex stabilities and rapid scavenging of Ho by Fe- and/or Mn- (hydro-) oxides lead seawaters to have Y/Ho atios of 50-60 (Koschinsky et al., 1997; Minami et al., 1998; Madhavaraju et al., 2010). Previous studies shown that the Y/Ho ratio rapidly decreases in marine deposits due to input of terrigenous source particles (i.e., felsic and basaltic composition) into sedimentary environment (Bau et al., 1996; Webb and Kamber, 2000; Bolhar et al., 2004). Based upon the analytical data (Table 3), the $\mathrm{Y} / \mathrm{Ho}$ ratios of the limestone samples in this district vary from 3.97 to 61.43 (Fig. 7).

As Figure 8a displays, the $\mathrm{Y} / \mathrm{Ho}$ ratios remain relatively low in samples from (L-1) to (L-10) and show sudden increase in samples from (L-10) to (L15). Therefore, it can be deduced that input of terrigenous source materials in the lower part of Ruteh 
Table 3 The calculated geochemical parameters of the limestone samples.

\begin{tabular}{lrrrrrrrrrrrrrrr}
\hline & \multicolumn{1}{c}{ L-1 } & \multicolumn{1}{c}{ L-2 } & \multicolumn{1}{c}{ L-3 } & \multicolumn{1}{c}{ L-4 } & \multicolumn{1}{c}{ L-5 } & \multicolumn{1}{c}{ L-6 } & \multicolumn{1}{c}{ L-7 } & L-8 & L-9 & L-10 & L-11 & L-12 & L-13 & L-14 & L-15 \\
\hline Eu/Eu* & 1.19 & 1.17 & 1.20 & 1.18 & 1.15 & 1.11 & 1.12 & 1.15 & 1.18 & 1.10 & 1.46 & 1.48 & 1.44 & 1.62 & 1.69 \\
$\mathrm{Ce} / \mathrm{Ce}^{*}$ & 0.93 & 0.92 & 0.91 & 0.91 & 0.95 & 0.93 & 0.94 & 0.88 & 0.95 & 0.91 & 1.02 & 1.13 & 1.27 & 1.12 & 1.12 \\
$\mathrm{Y} / \mathrm{Ho}$ & 20.48 & 23.89 & 3.97 & 26.47 & 21.9 & 15 & 6.35 & 23.68 & 10 & 25.29 & 36.19 & 38.1 & 31.74 & 46.11 & 61.43 \\
$\mathrm{Zr} / \mathrm{Hf}$ & 24.29 & 30.83 & 31.82 & 31.67 & 27.14 & 29.09 & 30.83 & 25.00 & 31.67 & 31.67 & 19.58 & 22.17 & 18.75 & 20.38 & 17.50 \\
$\mathrm{~T}_{1}$ & 0.23 & 0.27 & 0.27 & 0.25 & 0.24 & 0.24 & 0.23 & 0.26 & 0.22 & 0.28 & 0.21 & 0.50 & 0.36 & 0.20 & 0.19 \\
$\mathrm{~T}_{3}$ & 0.24 & 0.28 & 0.71 & 0.17 & 0.32 & 0.15 & 0.61 & 0.27 & 0.48 & 0.28 & 0.24 & 0.14 & 0.15 & 0.15 & 0.13 \\
$\mathrm{~T}_{4}$ & 0.17 & 0.12 & 0.21 & 0.05 & 0.10 & 0.18 & 0.16 & 0.14 & 0.19 & 0.25 & 0.15 & 0.33 & 0.38 & 0.31 & 0.27 \\
\hline
\end{tabular}

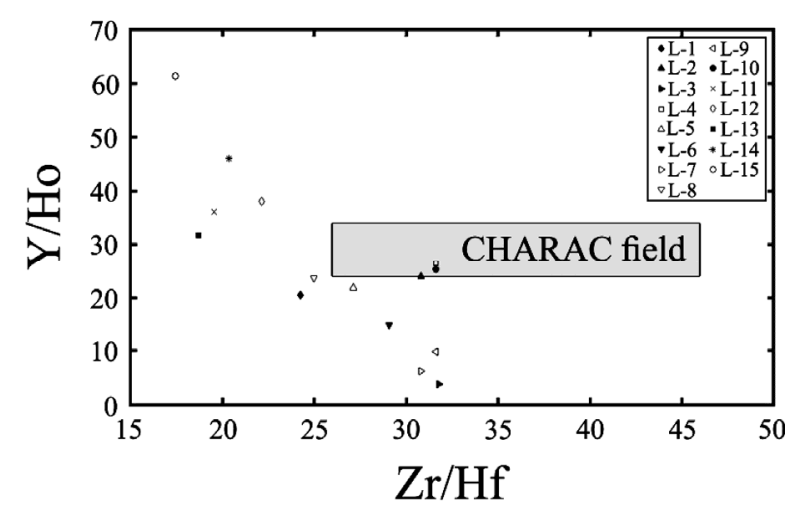

Fig. 9 Bivariate plot of $\mathrm{Zr} / \mathrm{Hf}$ vs. Y/Ho ratios of the limestone samples within the Ruteh Formation in the Kanigorgeh district. The CHARAC field is from Bau (1996).

Formation at Kanigorgeh district were probably played an important role in decreasing $\mathrm{Y} / \mathrm{Ho}$ ratios, whereas the upper part of the stratigraphic column was likely affected much less by terrigenous source materials and hence shows a remarkable increase in Y/Ho values.

The tetravalent elements such as $\mathrm{Zr}$ and $\mathrm{Hf}$ also show similar behavior which is due to their analogous ionic charge and radius in various geological environments (Bau, 1996). Non-CHARAC ratios of such geochemically isovalent pairs can be caused by tetrad effect phenomenon and could be used as geochemical indicator for environmental conditions and source identification (Bau, 1996). The $\mathrm{Zr} / \mathrm{Hf}$ ratios of the limestone samples in this district vary from 17.5 to 31.82 (Table 3 ) which is characterized by two populations (Fig. 8b). The first population belongs to samples from L-1 to L-10 (in lower part of the Ruteh Formation) which has $\mathrm{Zr} / \mathrm{Hf}$ ratios within the CHARAC field. The second population represents samples from L-11 to L-15 (in upper part of the Ruteh Formation) with higher $\mathrm{Zr} / \mathrm{Hf}$ ratios, and display nonCHARAC behavior. As illustrated in Figure 9, the samples represent non-CHARAC behavior except for samples L-2, L-4, and L-10. This indicates that the limestone was precipitated in a non-CHARAC depositional environment.
Bau (1996) suggested that non-smooth or irregular curves of normalized REE distribution patterns and non-CHARAC behavior of geochemically isovalent pairs, despite their coherency, in geological environments can be related to geochemical processes such as tetrad effect phenomenon.

\subsection{THE SIZE OF TETRAD EFFCET PHENOMENON}

Various mathematically-based methods have been used to compute the size of tetrad effect phenomenon in normalized REE distribution patterns (Irber, 1999; Monecke et al., 2002). Based on these methods, the size of each tetrad effect is computed and symbolized as $T_{1}, T_{2}, T_{3}$, and $T_{4}$ representing for the first (La-Ce-Pr-Nd), second (Pm-Sm-Eu-Gd), third (Gd-Tb-Dy-Ho), and fourth (Er-Tm-Yb-Lu) tetrad group, respectively. By applying the concentration values of four lanthanide elements in each tetrad group, The size of $\mathrm{T}_{\mathrm{i}}(\mathrm{i}=1,2,3$, and 4$)$ is computed by the following equation (4) proposed by Monecke et al. (2002):

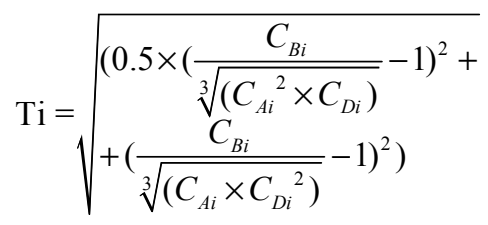

In this equation, the concentration values of $1^{\text {st }}$, $2^{\text {nd }}$ and $3^{\text {rd }}$, and $4^{\text {th }}$ elements in each tetrad group are shown as $\mathrm{C}_{\mathrm{Ai}}, \mathrm{C}_{\mathrm{Bi}}, \mathrm{C}_{\mathrm{Ci}}$, and $\mathrm{C}_{\mathrm{Di}}$, respectively. If all lanthanide elements of each group are on a straight line, the $T_{i}$ value will be zero indicating that no tetrad effect occurred. But, if the $T_{i}$ value is not zero, it means that the second and the third lanthanide elements depart from the straight line between the first and fourth lanthanide elements of an individual tetrad group and can be interpreted as tetrad effect phenomenon. Since Pm does not occur in natural geological environments, it is customary that the size of $T_{i}$ is calculated for three lanthanide tetrad groups, and the $\mathrm{T}_{2}$ for the second tetrad is not computed (McLennan, 1994). If a striking Ce anomaly exists in 


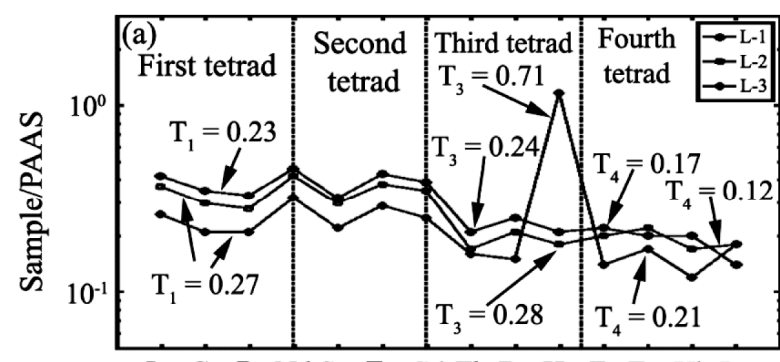

La Ce Pr Nd Sm Eu Gd Tb Dy Ho Er Tm Yb Lu

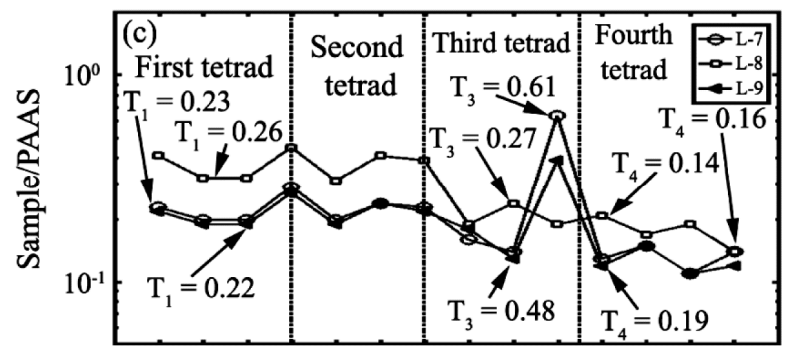

La Ce Pr Nd Sm Eu Gd Tb Dy Ho Er Tm Yb Lu
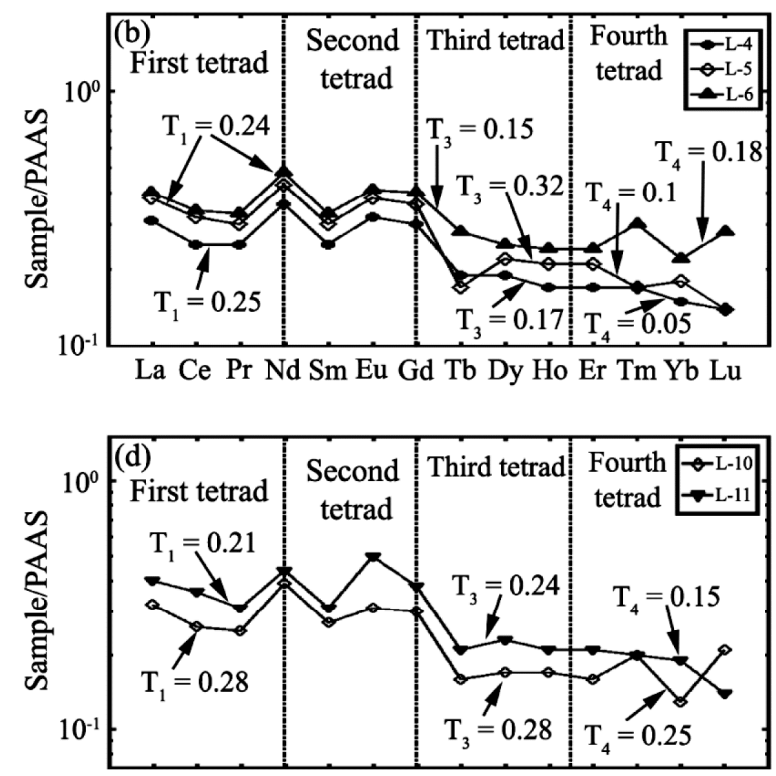

La Ce Pr Nd Sm Eu Gd Tb Dy Ho Er Tm Yb Lu

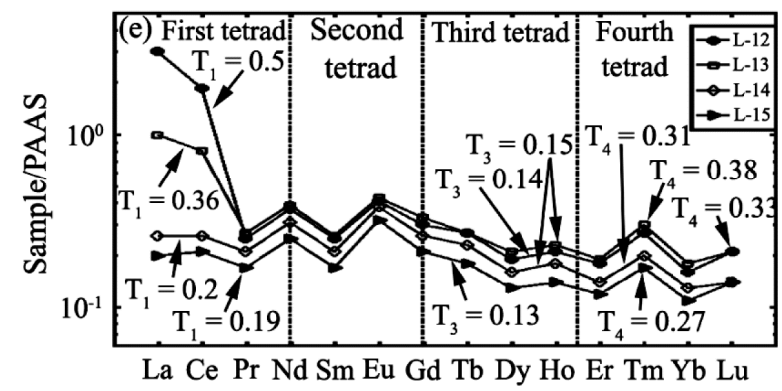

Fig. 10 PAAS-normalized REE distribution pattern of the limestone samples within the Ruteh Formation showing the computed size of the first, third, and fourth tetrads by following method of Monecke et al. (2002). (a) L-1 to L-3, (b) L-4 to L-6, (c) L-7 to L-9, (d) L-0 to L-11, and (e) L-12 to L-15.
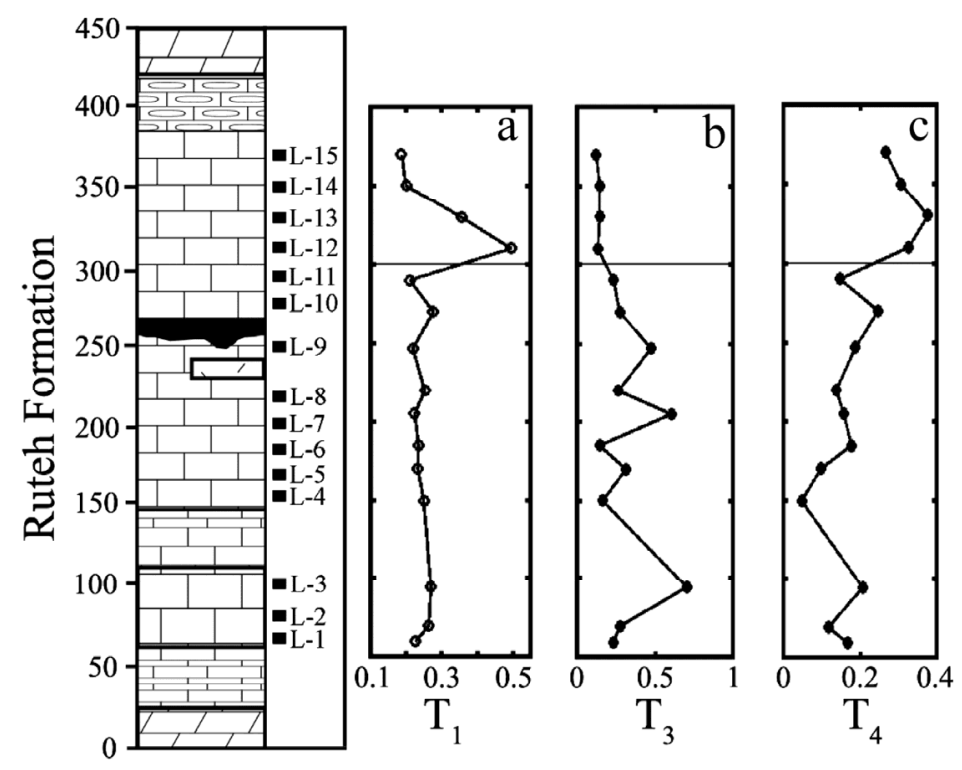

Fig. 11 Variations of (a) $T_{1}$, (b) $T_{3}$, and (c) $T_{4}$ tetrad effect values of the studied limestone samples within the Ruteh Formation in the Kanigorgeh district. Horizontal lines indicate zone of variation in tetrad effect trend as an indicative of changing in depositional conditions. 
Table 4 The calculated size and shape of tetrad in each tetrad segments of the limestone samples.

\begin{tabular}{|c|c|c|c|c|c|c|}
\hline \multirow[b]{2}{*}{ Sample No. } & \multicolumn{3}{|c|}{ First tetrad } & \multirow{2}{*}{$\begin{array}{c}\text { Third tetrad } \\
\text { Shape }\end{array}$} & \multicolumn{2}{|c|}{ Fourth tetrad } \\
\hline & Size & Shape & Size & & Size & Shape \\
\hline L-1 & 0.23 & Concave & 0.24 & Concave & 0.17 & Convex \\
\hline L-2 & 0.27 & Concave & 0.28 & Concave & 0.12 & Convex \\
\hline L-3 & 0.27 & Concave & 0.71 & Concave & 0.21 & Concave \\
\hline L-4 & 0.25 & Concave & 0.17 & Concave & 0.05 & Convex \\
\hline $\mathrm{L}-5$ & 0.24 & Concave & 0.32 & Concave & 0.10 & Convex \\
\hline L-6 & 0.24 & Concave & 0.15 & Concave & 0.18 & Concave \\
\hline L-7 & 0.23 & Concave & 0.61 & Concave & 0.16 & Concave \\
\hline L-8 & 0.26 & Concave & 0.27 & Concave & 0.14 & Convex \\
\hline L-9 & 0.22 & Concave & 0.48 & Concave & 0.19 & Concave \\
\hline L-10 & 0.28 & Concave & 0.28 & Concave & 0.25 & Concave \\
\hline L-11 & 0.21 & Concave & 0.24 & Concave & 0.15 & Convex \\
\hline L-12 & 0.50 & Concave & 0.14 & Concave & 0.33 & Concave \\
\hline L-13 & 0.36 & Concave & 0.15 & Concave & 0.38 & Concave \\
\hline L-14 & 0.20 & Concave & 0.15 & Concave & 0.31 & Concave \\
\hline L-15 & 0.19 & Concave & 0.13 & Concave & 0.27 & Concave \\
\hline
\end{tabular}

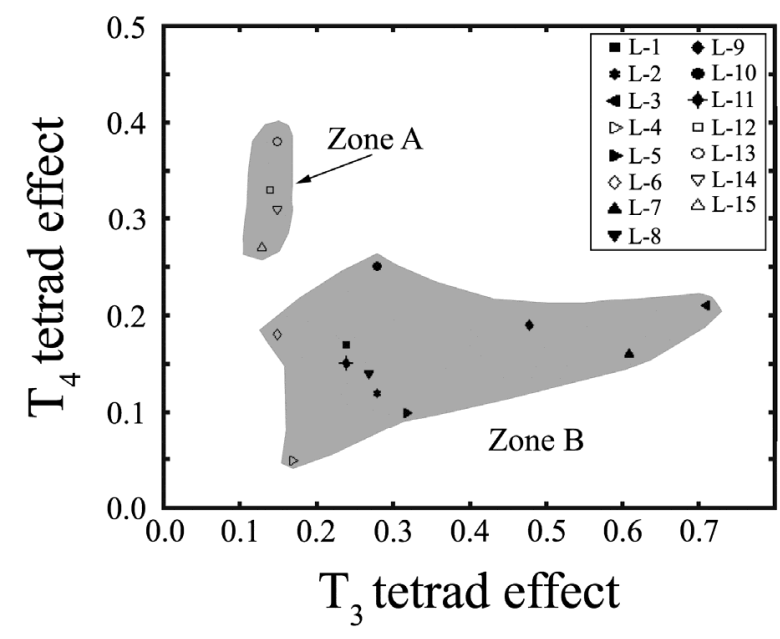

Fig. 12 Scatter plots of the size of $\mathrm{T}_{3}$ vs. $\mathrm{T}_{4}$ tetrad effect in the limestone samples of the Ruteh Formation. Zone A includes samples with remarkably higher values of $\mathrm{T}_{4}$ and very low $\mathrm{T}_{3}$ tetrad effect. Zone $\mathrm{B}$ comprises the samples with lesser values of $\mathrm{T}_{4}$ and a wide variation in $\mathrm{T}_{3}$ tetrad effect.

the first group of lanthanide elements, the size of $T_{1}$ must be ignored in calculation processes (Monecke et al., 2002).

The computed size of $T_{1}, T_{3}$, and $T_{4}$ for limestone samples of the Ruteh Formation are listed in Table 3. The size of tetrad effect and form of curves in each tetrad segment are represented in Table 4 . The first tetrad values vary from 0.19 to 0.50 (Fig. 11a), and all the data points have concave tetrad effect form. The third tetrad values have a range of $0.13-$ 0.71 (Fig. 11b), and the data points display concave shape. The size of fourth tetrad varies from 0.05 to 0.38 (Fig. 11c), and the data points show both concave and convex tetrad effect forms. As shown in Figs. 10a-e, the first tetrad of all limestone samples of the Ruteh Formation represents typical concave (Wshape) curve in PAAS-normalized REE distribution patterns which is indicative of low-temperature depositional conditions. Based on the results of computed tetrad effect values (Table 4), it is clear that the size of tetrad effect in the limestone has different variation trends.

\subsection{CORRELATION BETWEEN THE SIZE OF TETRAD EFFECT WITH GEOCHEMICAL PARAMETERS}

Figure 12 illustrates the correlation between the size of $\mathrm{T}_{3}$ and $\mathrm{T}_{4}$ in the studied samples. The samples are categorized in two different populations with various $T_{3}$ and $T_{4}$ values. The first population includes samples from L-12 to L-15 with a very narrow $\mathrm{T}_{3}$ and remarkably higher $\mathrm{T}_{4}$ (see Zone $\mathrm{A}$ in Fig. 12). In contrast, the second population (see Zone B in Fig. 12) includes samples from L-1 to L-11 with a wide variation in $T_{3}$ and lower $T_{4}$. In fact, Figure 12 represents Cartesian coordinate system in which each point within the system has a unique $\mathrm{x}\left(\mathrm{T}_{3}\right)$ and $\mathrm{y}\left(\mathrm{T}_{4}\right)$. The third $\left(\mathrm{T}_{3}\right)$ and fourth $\left(\mathrm{T}_{4}\right)$ tetrad effects were combined to quantify a new parameter so-called polar values by using the polar coordinate system. In the polar coordinate system at each point on a plan is determined by $r$ (distance from the point of origin) and $\theta$ (an angle from reference direction). In this research, the relation between $T_{3}$ and $T_{4}$ tetrad effect in Cartesian coordinate system and their polar values can be calculated by using the following equations:

$\operatorname{tg} \theta=\frac{T_{4}}{T_{3}}$

$\mathrm{r}=\sqrt{T_{3}^{2}+T_{4}^{2}}$

$T_{p}=\mathrm{r} \times \operatorname{tg} \theta$

The $T_{p}$ is a combination of both $T_{3}$ and $T_{4}$ tetrad effect values in polar system which affects the distribution of REE in geochemical systems. In polar coordinate system each point on a plan has a unique $\mathrm{r} \times \operatorname{tg} \theta$. To quantify correlation between third and 
Table 5 The calculated values for $r, \operatorname{tg} \theta$, and $T_{p}$ for the limestone samples of the Ruteh Formation.

\begin{tabular}{lccc}
\hline Sample No. & $\operatorname{tg} \theta$ & $\mathrm{r}$ & $\mathrm{T}_{\mathrm{p}}=\mathrm{r} \times \operatorname{tg} \theta$ \\
\hline L-1 & 0.71 & 0.29 & 0.21 \\
L-2 & 0.43 & 0.30 & 0.13 \\
L-3 & 0.30 & 0.74 & 0.22 \\
L-4 & 0.29 & 0.18 & 0.05 \\
L-5 & 0.31 & 0.34 & 0.10 \\
L-6 & 1.20 & 0.23 & 0.28 \\
L-7 & 0.26 & 0.63 & 0.17 \\
L-8 & 0.52 & 0.30 & 0.16 \\
L-9 & 0.40 & 0.52 & 0.20 \\
L-10 & 0.89 & 0.38 & 0.34 \\
L-11 & 0.63 & 0.28 & 0.18 \\
L-12 & 2.36 & 0.36 & 0.84 \\
L-13 & 2.53 & 0.41 & 1.03 \\
L-14 & 2.07 & 0.34 & 0.71 \\
L-15 & 2.08 & 0.30 & 0.62 \\
\hline
\end{tabular}

fourth tetrad effect values with other geochemical parameters, the $\mathrm{T}_{\mathrm{p}}$ of each sample was computed (Table 5).

Correlation between the size of $\mathrm{T}_{\mathrm{p}}$ versus $\mathrm{Ce}$ anomaly, Eu anomaly, Y/Ho ratio, and $\mathrm{Zr} / \mathrm{Hf}$ ratio of the studied samples are illustrated in Figures 13a-d. As shown in these figures, the samples can be divided into two separate groups reflecting different depositional conditions for each group. This hypothesis is consistent with non-CHARAC behavior of geochemically similar Y, Ho, Zr, and Hf elements (Fig. 9) which can be related to tetrad effect occurrence. As shown in Figure 13a, the samples are divided into two zones. The differentiation of $\mathrm{Ce}$ anomalies on the basis of $T_{p}$ is indicative of variation
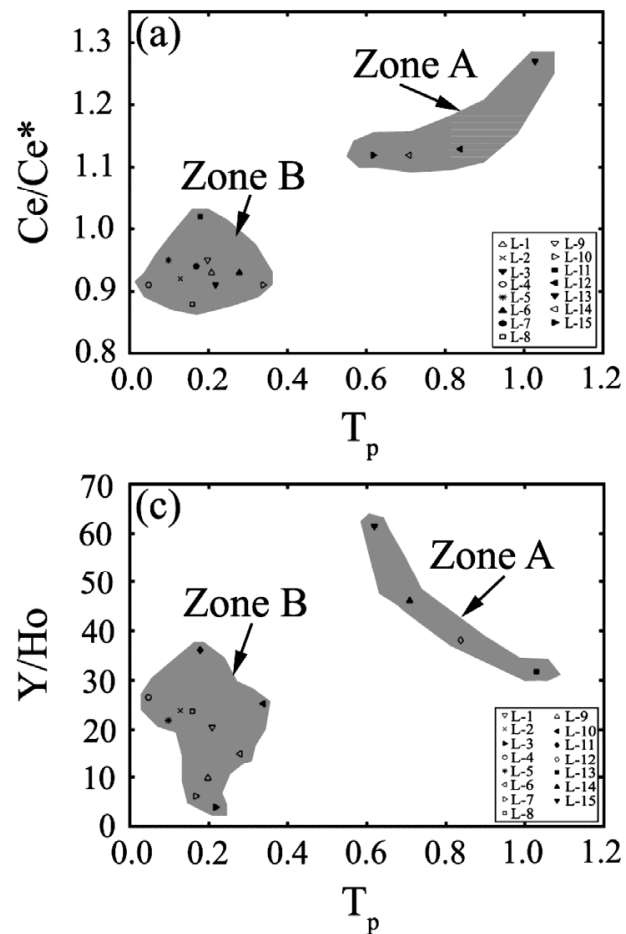

in physico-chemical conditions during precipitation of the limestones. Ce as a redox sensitive sensitive element can be used as an indicator for evaluation of oxygen fugacity of depositional environment (Klinkhammer et al., 1983; Hannigan et al., 2010; Kraemer et al., 2016; Dill et al., 2011, 2014, 2016). The oxidation of soluble $\mathrm{Ce}^{3+}$ (reduced) into less soluble $\mathrm{Ce}^{4+}$ (oxidized) under oxic seawaters causes negative $\mathrm{Ce}$ anomalies, whereas alkalic waters rich in carbonates likely cause the stabilization of polycarbonate-Ce complexes in seawaters (Bau and Dulski, 1996; Madhavaraju and González-León, 2012) and hence remarkably positive Ce anomaly in sediments such as the Lake Van in Turkey (Möller and Bau, 1993). This means that the limestone of the Zone A (L-12 to L-15) was precipitated likely under higher oxygen fugacity conditions from polycarbonate-rich alkalic waters. Meanwhile, the constant concave (W-form) tetrad effects in PAASnormalized REE distribution patterns of the Zone A (L-12 to L-15 samples) and pronounced tetrad effect in the computed $T_{p}$ values can be attributed to more stable depositional conditions. Therefore, it can be concluded that the Zone A (L-12 to L-15) was precipitated likely under relatively oxic shallow polycarbonate-rich alkalic seawaters. In contrast, the Zone B (L-1 to L-11 samples) displays coexisting concave (W-form) and convex (M-form) shapes of the tetrad effects and lesser $T_{p}$ values with negative Ce anomaly values (except in sample L-11). This complicated history is indicative of deeper depositional environment with suboxic conditions during the development of this part of the Ruteh Formation.
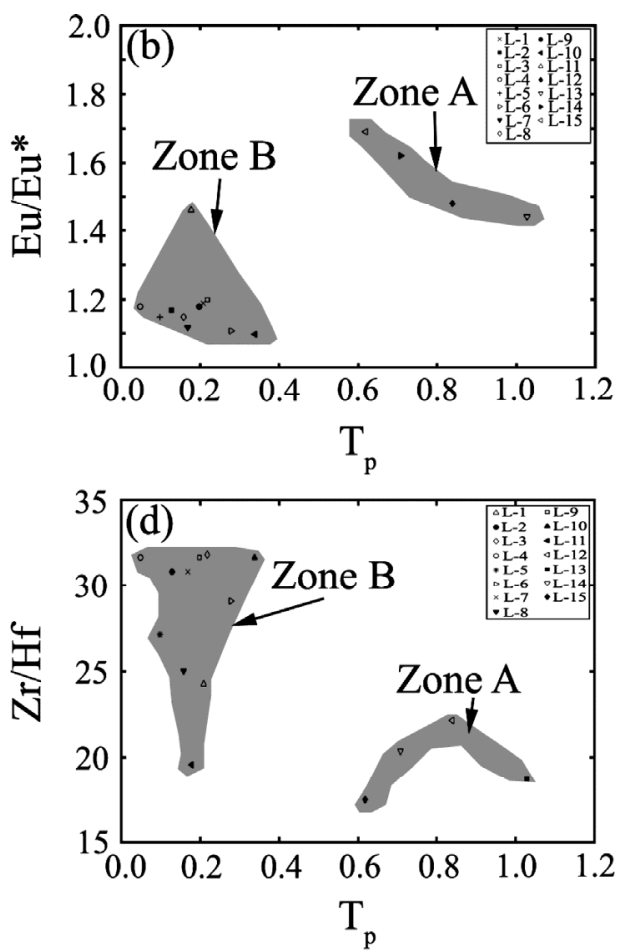

Fig. 13 Scatter plots the size of $\mathrm{T}_{\mathrm{p}} v s$. (a) Ce anomaly, (b) Eu anomaly, (c) Y/Ho ratios, and (d) $\mathrm{Zr} / \mathrm{Hf}$ ratios of the limestone samples. See text for details of Zone A and Zone B. 
The scatter pattern of the size of $T_{p}$ versus $\mathrm{Eu}$ anomaly in the samples indicates that there are two distinct zones in the Ruteh Formation, (1) zone A representing samples with high $\mathrm{T}_{\mathrm{p}}$ and $\mathrm{Eu}$ anomalies and (2) Zone B with lesser $\mathrm{T}_{\mathrm{p}}$ and $\mathrm{Eu}$ anomalies. Eu as an oxidation sensitive element among REE, and is strongly dependent on temperature of depositional conditions (Möller et al., 1998; Mondillo et al., 2015; Dill, 2016, 2017). In fact, at temperatures $>200^{\circ} \mathrm{C}$ $\mathrm{Eu}^{3+}$ is reduced to mobile $\mathrm{Eu}^{2+}$. Therefore, reduced $\mathrm{Eu}$ $\left(\mathrm{Eu}^{2+}\right)$ preferentially remains in solutions and causes negative anomaly in chemical/biochemical precipitates. In contrast, in low-temperature environments the immobile $\mathrm{Eu}^{3+}$ prevails and concentrates in chemical/biochemical carbonate precipitates, hence displaying positive Eu anomalies. As shown in Figure 6, Eu anomaly values of the samples increase from L-11 to L-15. Abedini and Calagari (2015) suggested that, both diagenetic processes and the presence of plagioclase in the limestone of the Ruteh Formation were two important factors for generation of the positive Eu anomaly. Furthermore, according to Figure 13b, the samples of the Zone A (L-12 to L-15) are characterized by high $\mathrm{T}_{\mathrm{p}}$ values and Eu anomalies, whereas the samples of the Zone B (L-1 to L-11) display a contrasting trend. Thus, it can be deduced that the existence of plagioclase as a mineral phase were probably played more pronounced role for generation of $\mathrm{Eu}$ anomalies in the Zone $\mathrm{A}$ than the diagenetic processes during development of the limestone under very low-temperature sedimentary conditions.

The bivariate plots of $T_{p}$ versus $Y / H o$ (Fig. 13c) and $\mathrm{Zr} / \mathrm{Hf}$ (Fig. 13d) ratios of the samples demonstrate two discrete groups of $T_{p}$ tetrad effect values within the limestone. The samples in the Zone B (L-1 to L-11) are characterized by low $\mathrm{Y} / \mathrm{Ho}$, high $\mathrm{Zr} / \mathrm{Hf}$ ratios and high $T_{p}$ tetrad effect values but in the Zone A, they exhibit contrasting trend, high $T_{p}$ tetrad effect and $\mathrm{Y} / \mathrm{Ho}$ ratios and low $\mathrm{Zr} / \mathrm{Hf}$ ratios. Both populations of the samples support the idea that depositional conditions of the Ruteh Formation had different characteristics. The $\mathrm{Y} / \mathrm{Ho}$ ratios of the samples are relatively low (Fig. 8a) in samples from L-1 to L-10 which may be due to adsorption of Ho on $\mathrm{Fe}-$ and/or $\mathrm{Mn}$ - oxides in the depositional environment. This ratio remains relatively constant in samples from L-11 to L-15 which may be pertained to relative predominance of $\mathrm{Y}$ over Ho. This inference is supported by the results of tetrad effect values $\left(T_{p}\right)$ of the samples which reflect two depositional conditions for the Ruteh Formation (Fig. 13c). Moreover, similar groups of samples can also be observed in scatter diagram of $\mathrm{Zr} / \mathrm{Hf}$ ratios versus $\mathrm{T}_{\mathrm{p}}$ tetrad effect values (Fig. 13d). According to the aforementioned results, it can be deduced that the limestone of the Ruteh Formation in the Kanigorgeh district was likely deposited under two different conditions.

\section{MECHANISMS FOR TETRAD EFFECT}

Many studies have shown that the main mechanisms and processes for occurrence of tetrad effect phenomenon are not very clear (Censi et al., 2007; Monecke et al., 2007; Inoue et al., 2009). But, based on recent investigations, some geochemicallybased models such as mineral phases during fractional mineralization, complexes in solutions, fluid-rock interaction, weathering, and hydrothermal alteration have been proposed by many researchers (Pan, 1997; Monecke et al., 2007; Badanina et al., 2010; Feng et al., 2011; Wu et al., 2011; Nardi et al., 2012; Abedini et al., 2017; Rezaei Azizi et al., 2017).

Generally, during igneous activities such as fractional mineralization and interaction of rising hydrothermal fluids with rocks along the channelways (faults and/or fractures), and complexing with ligands in hydrothermal systems are distinguished by convex (M-shape) tetrad effect curves in normalized REE distribution patterns (McLennan, 1994; Irber, 1999; Monecke et al., 2007). These authors suggested that anomalous behavior of $\mathrm{Eu}$ and occurrence of tetrad effect phenomenon are attributed to solution-rock interactions. Moreover, REE sorption on clay minerals can generate convex (M-shape) tetrad effect in the products of deposition (Feng et al., 2014). The XRD results carried out by Abedini and Calagari (2015) in some of the studied samples revealed that besides carbonates, quartz, plagioclase, and kaolinite were also abundant as rock forming mineral phases in the limestone samples of the Ruteh Formation. Existence of pronounced convex (M-shape) curves in PAASnormalized REE distribution patterns of these samples indicate that mineral phases and solution-rock interaction during deposition of the limestone were likely the main factors for the occurrence of tetrad effect phenomenon.

The concave or W-shape tetrad effect phenomenon is indicative of low temperature deposits such as marine carbonates, underground waters, phosphorites, phosphatic shales, cherts, low temperature hydrothermal deposits (Kawabe, 1996; Akagi et al., 2004; Feng et al., 2011; Feng et al., 2014; Abedini et al., 2017). In addition, recent studies indicate that concave form of the tetrad effect phenomenon can be attributed to distribution of REE in seawaters, diagenetic processes, and REEcomplexation (Minami et al., 1998; Cunha et al., 2012). Based on the current and previous data in this district, it can be deduced that the shallow marine depositional environment, diagenetic processes, and redistribution of REE by complexing ligand such as polycarbonates are likely some other mechanisms for deposition and distribution of REE and tetrad effect in the limestone.

Based on bivariate diagrams of $\mathrm{T}_{\mathrm{p}}$ values versus $\mathrm{Fe}_{2} \mathrm{O}_{3}$ (Fig. 14a), $\mathrm{Al}_{2} \mathrm{O}_{3}$ (Fig. 14b), $\mathrm{V}$ (Fig. 14c), and $\mathrm{Rb}$ (Fig. 14d), all the studied samples are divided into two separate populations (1) Zone A and (2) Zone B. The Zone A represents samples from L-12 to L-15 and the Zone B from L-1 to L-11 (see Fig. 14a). This separation can be related to the scavenging of rare earth elements by Fe-oxides which in turn as a controlling parameter played a significant role for generation of the tetrad effect in marine sedimentary 

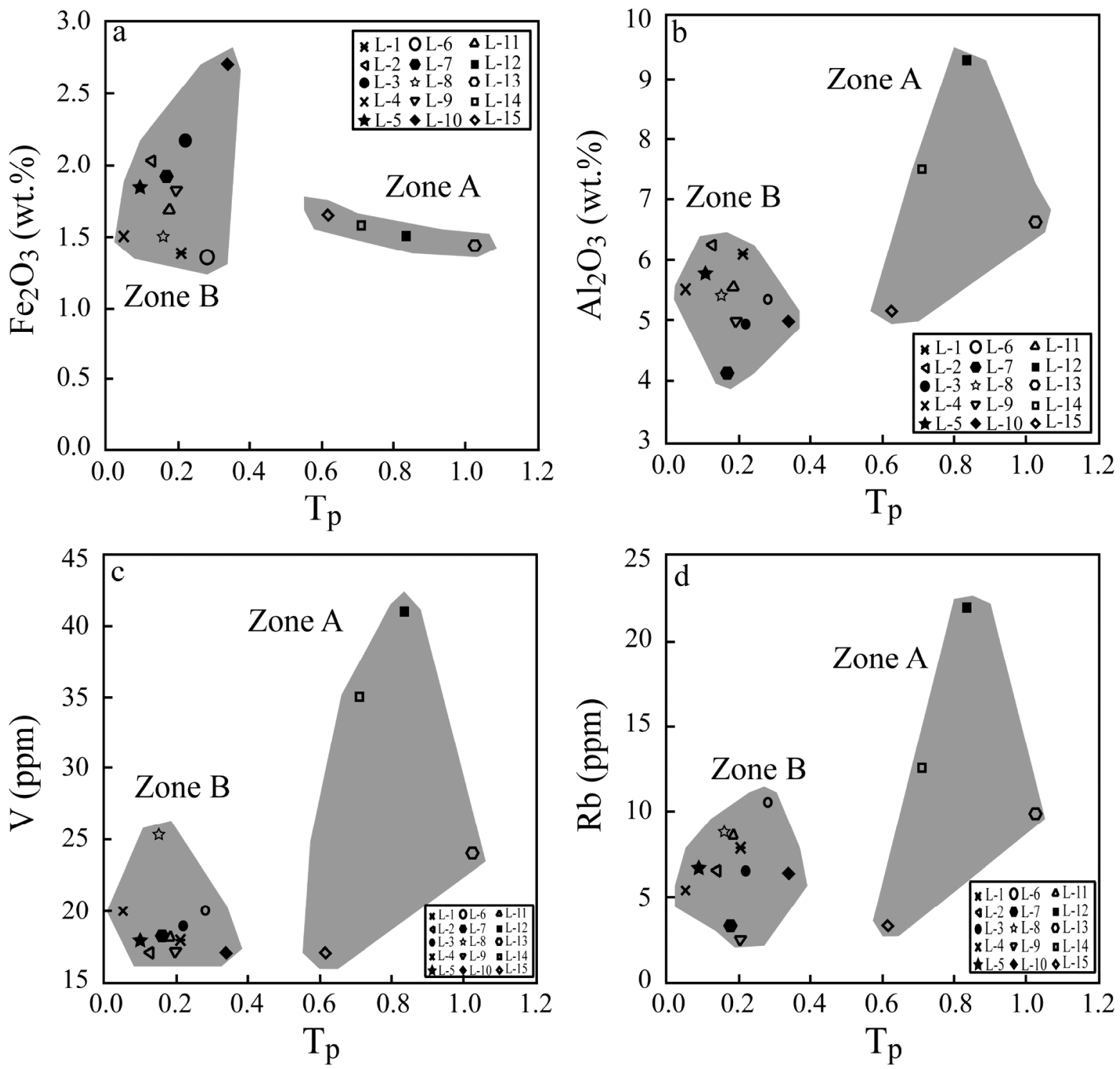

Fig. 14 Scatter plots the size of $\mathrm{T}_{\mathrm{p}} v s$. (a) $\mathrm{Fe}_{2} \mathrm{O}_{3}$, (b) $\mathrm{Al}_{2} \mathrm{O}_{3}$, (c) V, and (d) $\mathrm{Rb}$ concentrations of the limestone samples. See text for details of Zone A and Zone B.
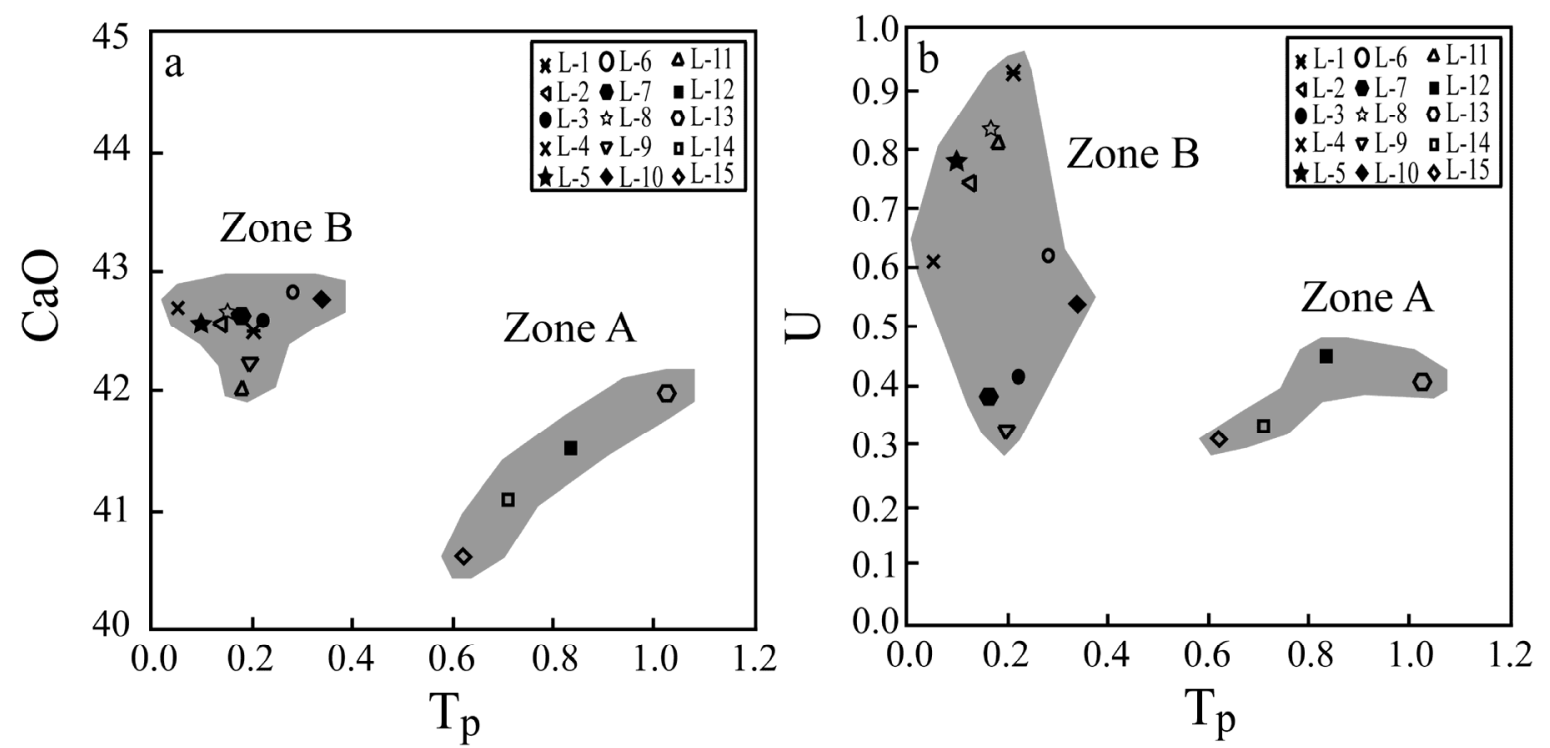

Fig. 15 Scatter plots of the $T_{p}$ tetrad effect values versus (a) $\mathrm{CaO}$ (wt.\%) and (b) $U$ (ppm) in the studied limestone samples within the Ruteh Formation. See text for details of Zone A and Zone B. 
environment of the studied area. Meanwhile, similar separated populations with different characteristics are observed on the bivariate plots of $\mathrm{T}_{\mathrm{p}}$ tetrad effect values versus $\mathrm{Al}_{2} \mathrm{O}_{3}$ (see Fig. 14b), $\mathrm{V}$ (see Fig. 14c), and $\mathrm{Rb}$ (see Fig. 14d) which can be likely attributed to variation in degree of detrital input to sedimentary environment. Therefore, it can be inferred that scavenging of REE by Fe-oxides and the degree of detrital input had likely crucial role in occurrence of the tetrad effect phenomenon in the study area.

The bivariate plots of $T_{p}$ tetrad effect values versus $\mathrm{CaO}$ (Fig. 15a) and $\mathrm{U}$ (Fig. 15b) content of the samples also delineate two distinct zones. The Zone A includes samples from L-12 to L-15 and the Zone B samples from L-1 to L-11. Either U (as an oxidation state sensitive element) or $\mathrm{CaO}$ can be used as paleoredox proxy. The Zone A (L-12 to L-15) represents samples with lower $\mathrm{CaO}$ and $\mathrm{U}$ content, and is characteristic of a relatively higher oxygen fugacity, but Zone B (L-1 to L-11) belongs to samples having relatively reduced condition. Therefore, it can be concluded that paleo-redox conditions of the sedimentary environment were likely another mechanism for controlling and existence of the tetrad effect in this area.

\section{CONCLUSIONS}

Based upon the concentration of major, trace, and REE elements in the limestone of the Ruteh Formation (NW Iran) and computed values for tetrad effect phenomenon and correlation of these values with $\mathrm{Y} / \mathrm{Ho}$ and $\mathrm{Zr} / \mathrm{Hf}$ ratios, $\mathrm{U}, \mathrm{CaO}, \mathrm{Fe}_{2} \mathrm{O}_{3}, \mathrm{Al}_{2} \mathrm{O}_{3}, \mathrm{~V}$, and $\mathrm{Rb}$, we have reached the following conclusions:

1. The co-occurrence of concave and convex tetrad effect forms in PAAS-normalized REE distribution patterns can be used as a good and powerful geochemical indicator to evaluate the paleo physico-chemical conditions.

2. Existence of the convex (M-shaped) tetrad effect form in Zone B (the lower part of the limestone) can be probably attributed to the presence of minor mineral phases such as kaolinite and plagioclase. In contrast, the concave (W-shaped) tetrad effect form is indicative of marine sedimentation.

3. The correlation between the computed size of tetrad effect in polar coordination system (Tp) and geochemical parameters (Ce-Eu anomalies, $\mathrm{Y} / \mathrm{Ho}$ and $\mathrm{Zr} / \mathrm{Hf}$ ratios) indicate two separate zones (Zone A and Zone B) with different characteristics. It means that the Zone A was likely deposited under relatively stable oxic shallow polycarbonate-rich alkalic seawaters while the Zone B probably experienced deeper sub-oxic depositional conditions with input of more terrigenous materials.

4. Mineral phases, REE-complexing, adsorption of REE by clay minerals, solution-rock interaction, and diagenetic processes are most likely the main factors and mechanisms responsible for the occurrence of tetrad effect in the limestone.
5. The separation of two zones (Zone A and Zone B) in the bivariate plots of $T_{p}$ tetrad effect values versus $\mathrm{Fe}_{2} \mathrm{O}_{3}, \mathrm{Al}_{2} \mathrm{O}_{3}, \mathrm{CaO}, \mathrm{V}, \mathrm{U}$, and $\mathrm{Rb}$ can be due to the scavenging of REE by Fe-oxides and input of varying amounts of detrital materials as a possible mechanism for the tetrad effect occurrence.

\section{ACKNOWLEDGEMENTS}

This work was supported financially by the Research Bureau of Urmia University. The authors would like to express their thanks and gratitude to the authorities of this bureau. Our gratitude is further expressed to Prof. Josef Stemberk, Dr. Monika Šupová, and two other anonymous reviewers for reviewing our manuscript and making critical comments and valuable suggestions, which have definitely improved the quality of this work.

\section{REFERENCES}

Abedini, A. and Calagari, A.A.: 2013a, Rare earth elements geochemistry of Sheikh-Marut laterite deposit, NW Mahabad, West-Azarbaidjan province, Iran. Acta Geologica Sinica, English Series, 87, 176-185. DOI: $10.1111 / 1755-6724.12039$

Abedini, A. and Calagari, A.A.: 2013b, Geochemical characteristics of bauxites: the Permian Shahindezh horizon, NW Iran. Neues Jahrbuch für Geologie und Paläontologie Abhandlungen, 270, 301-324.

Abedini, A. and Calagari, A.A.: 2013c, Geochemical characteristics of Kanigorgeh ferruginous bauxite horizon, West-Azarbaidjan province, NW Iran. Periodico di Mineralogia, 82, 1-23. DOI: $10.1127 / 0077-7749 / 2013 / 0371$

Abedini, A. and Calagari, A.A.: 2014, REE geochemical characteristics of titanium-rich bauxites: the Permian Kanigorgeh horizon, NW Iran. Turkish Journal of Earth Sciences, 23, 513-532. DOI: $10.3906 /$ yer-1404-11

Abedini, A. and Calagari, A.A.: 2015, Rare earth element geochemistry of the Upper Permian limestone: the Kanigorgeh mining district, NW Iran. Turkish Journal of Earth Sciences, 24, 365-382. DOI: $10.3906 /$ yer-1412-30

Abedini, A., Calagari, A.A. and Rezaei Azizi, M.: 2018, The tetrad-effect in rare earth elements distribution patterns of titanium-rich bauxites: Evidence from the Kanigorgeh deposit, NW Iran. Journal of Geochemical Exploration, 186, 129-142. DOI: $10.1016 / 2017.12 .007$

Abedini, A., Rezaei Azizi, M., Calagari, A.A. and Cheshmehsari, M.: 2017, Rare earth element geochemistry and tetrad effects of the Dalir phosphatic shales, northern Iran. Neues Jahrbuch für Geologie und Paläontologie Abhandlungen, 286, 169-188. DOI: 10.1127/njgpa/2017/0693

Aghanabati, A.: 2004, Geology of Iran. Tehran, Iran: Geological Survey of Iran, (in Persian).

Akagi, T., Hashimoto, Y., Fu, F.F., Tsuno, H., Tao, H. and Nakano, Y.: 2004, Variation of the distribution coefficients of rare earth elements in modern corallattices: Species and site dependencies. Geochimica et Cosmochimica Acta, 68, 2265-2273.

DOI: $10.1016 /$ j.gca 2003.12.014 
Armstrong-Altrin, J.S., Verma, S.P., Madhavaraju, J., Lee, Y.I. and Ramasamy, S.: 2003, Geochemistry of Late Miocene Kudankulam Limestones, South India. International Geology Review, 45, 16-26. DOI: $10.2747 / 0020-6814.45 .1 .16$

Badanina, E.V., Syritso, L.F., Volkova, E.V., Thomas, R. and Trumbull, R.B.: 2010, Composition of Li-F granite melt and its evolution during the formation of the ore-bearing Orlovka massif in Eastern Transbaikalia. Petrology, 18, 131-157. DOI: $10.1134 / \mathrm{S} 0869591110020037$

Bau, M. and Dulski, P.: 1996, Comparative study of yttrium and rare earth element behaviors in fluorine-rich hydrothermal fluids. Contributions Mineralogy and Petrology, 119, 213-223. DOI: 10.1007/BF00307282

Bau, M., Koschinsky, A., Dulski, P. and Hein, J.R.: 1996, Comparison of the partitioning behaviours of yttrium, rare earth elements, and titanium between hydrogenetic marine ferromanganese crusts and seawater. Geochimica et Cosmochimica Acta, 60, 1709-1725. DOI: 10.1016/0016-7037(96)00063-4

Bau, M.: 1996, Controls on the fractionation of isovalent trace elements in magmatic and aqueous systems: evidence from $\mathrm{Y} / \mathrm{Ho}, \mathrm{Zr} / \mathrm{Hf}$, and lanthanide tetrad effect. Contributions to Mineralogy and Petrology, 123, 323-333. DOI: 10.1007/s004100050159

Bolhar, R. and Van Kranendonk, M.J.: 2007, A non-marine depositional setting for the northern Fortescue Group, Pilbara Craton, inferred from trace element geochemistry of stromatolitic carbonates. Precambrian Research, 155, 229-250.

DOI: 10.1016/j.precamres.2007.02.002

Bolhar, R., Kamber, B.S., Moorbath, S., Fedo, C.M. and Whitehouse, M.J.: 2004, Characterisation of early Archaean chemical sediments by trace element signatures. Earth and Planetary Science Letters, 222, 43-60. DOI: 10.1016/j.eps1.2004.02.016

Byrne, R.H., Liu, X. and Schijf, J.: 1996, The influence of phosphate coprecipitation on rare earth element distributions in natural waters. Geochimica et Cosmochimica Acta, 60, 3341-3346. DOI: 10.1016/0016-7037(96)00197-4

Cantrell, K.J. and Byrne, R.H.: 1987, Rare earth element complexation by carbonate and oxalate ions. Geochimica et Cosmochimica Acta 51, 597-605. DOI: 10.1016/0016-7037(87)90072-X

Cao, M.J., Zhou, Q.F., Qin, K.Z., Tang, D.M. and Evans, N.J.: 2013, The tetrad effect and geochemistry of apatite from the Altay Koktokay No. 3 pegmatite, Xinjiang, China: Implications for pegmatite petrogenesis. Mineralogy and Petrology, 107, 9851005. DOI: $10.1007 / \mathrm{s} 00710-013-0270-\mathrm{x}$

Censi, P., Sprovieri, M., Saiano, F., Di Geronimo, S.I., Larocca, D. and Placenti, F.: 2007, The behavior of REEs in Thailand's Mae Klong estuary: Suggestions from the $\mathrm{Y} / \mathrm{Ho}$ ratios and lanthanide tetrad effects. Estuarine, Coastal and Shelf Science, 71, 569-579. DOI: 10.1016/j.ecss.2006.09.003

Cunha, M.C.L., Nardi, L.V.S. and Müller, I.F.: 2012, Biogeochemistry of REE elements and tetrad effect in plants from volcanic soils in southernmost Brazil. Anais da Academia Brasileira de Ciências, 84, 911918. DOI: 10.1590/S0001-37652012005000069

Dill, H.G., Hansen, B.T. and Weber, B.: 2011, REE contents, REE minerals and $\mathrm{Sm} / \mathrm{Nd}$ isotopes of granite- and unconformity-related fluorite mineralization at the western edge of the Bohemian Massif: with special reference to the NabburgWölsendorf District, SE Germany. Ore Geology Reviews, 40, 132-148. DOI: $10.1016 / j$.oregeorev.2011.06.003

Dill, H.G., Nolte, N. and Hansen, B.T.: 2014, Lithology, mineralogy and geochemical characterizations of sediment-hosted Sr-F deposits in the eastern NeoTethyan Region - with special reference to evaporation and halokinesis in Tunisia. Journal of African Earth Sciences, 92, 76-96. DOI: $10.1016 / j$.jafrearsci.2014.01.009

Dill, H.G., Luna, L.I., Nolte, N. and Hansen, B.T.: 2016, Chemical, isotopic and mineralogical characteristics of volcanogenic epithermal fluorite deposits on the Permo-Mesozoic foreland of the Andean volcanic arc in Patagonia (Argentina). Chemie der ErdeGeochemistry, 76, 275-297.

DOI: $10.1016 /$ j.chemer.2016.03.002

Dill, H.G.: 2016, Kaolin: soil, rock and ore From the mineral to the magmatic, sedimentary, and metamorphic environments. Earth Sciences Reviews, 161, 16-129. DOI: 10.1016/j.earscirev.2016.07.003

Dill, H.G.: 2017, Residual clay deposits on basement rocks: The impact of climate and the geological setting on supergene argillitization in the Bohemian Massif (Central Europe) and across the globe. Earth Sciences Reviews, 165: 1-58.

DOI: $10.1016 /$ j.earscirev.2016.12.004

Elderfield, H. and Greaves, M.J.: 1982, The rare earth elements in seawater. Nature 296, 214-219. DOI: $10.1038 / 296214 \mathrm{a} 0$

Elderfield, H., Upstill-Goddard, R. and Sholkovitz, E.R.: 1990, The rare earth elements in rivers, estuaries, and coastal seas and their significance to the composition of ocean waters. Geochimica et Cosmochimica Acta, 54, 971-991. DOI: 10.1016/0016-7037(90)90432-K

Feng, J.L., Gao, S.P. and Zhang, J.F.: 2011, Lanthanide tetrad effect in ferromanganese concretions and terra rossa overlying dolomite during weathering. Chemie der Erde, 71, 349-362. DOI: $10.1016 /$ j.chemer.2011.06.001

Feng, J.L., Zhao Z.H., Chen F. and Hu H.P.: 2014, Rare earth elements in sinters from the geothermal aters (hot springs) on the Tibetan Plateau, China. Journal of Volcanology and Geothermal Research, 287, 1-11. DOI: 10.1016/j.jvolgeores.2014.09.009

Fidelis, I. and Siekierski, S.: 1966, The regularities in stability constants of some rare earth complexes. Journal of Inorganic and Nuclear Chemistry, 28, 185188. DOI: $10.1016 / 0022-1902(66) 80243-9$

Frimmel, H.E.: 2009, Trace element distribution in Neoproterozoic carbonates as palaeoenvironmental indicator. Chemical Geology, 258, 338-353. DOI: 10.1016/j.chemgeo.2008.10.033

Gadd, M.G., Layton-Matthews, D. and Peter, J.M.: 2016, Non-hydrothermal origin of apatite in SEDEX mineralization and host rocks of the Howard's Pass district, Yukon, Canada. American Mineralogist, 101, 1061-1071. DOI: 10.2138/am-2016-5550

Greaves, M.J., Elderfield, H. and Sholkovitz, E.R.: 1999, Aeolian sources of rare earth elements to the Western Pacific Ocean. Marine Chemistry, 68, 31-38. DOI: 10.1016/S0304-4203(99)00063-8

Hannigan R., Dorval E. and Jones C.: 2010, The rare earth element chemistry of estuarine surface sediments in 
the Chesapeake Bay. Chemical Geology, 272, 20-30. DOI: 10.1016/j.chemgeo.2010.01.009

Hofmann, A.W.: 1997, Mantle geochemistry: the message from oceanic volcanism. Nature, 385, 219-229. DOI: $10.1038 / 385219 \mathrm{a} 0$

Inoue, M., Nakamura, N. and Kimura, M.: 2009, Tetrad effects in REE abundance patterns of chondrules from $\mathrm{CM}$ meteorites: Implications for aqueous alteration on the CM parent asteroid. Geochimica et Cosmochimica Acta, 73, 5224-5239.

DOI: $10.1016 /$ j.gca.2008.10.043

Irber, W.: 1999, The lanthanide tetrad effect and its correlation with $\mathrm{K} / \mathrm{Rb}, \mathrm{Eu} / \mathrm{Eu}^{*}, \mathrm{Sr} / \mathrm{Eu}, \mathrm{Y} / \mathrm{Ho}$, and $\mathrm{Zr} / \mathrm{Hf}$ of evolving peraluminous granite suites. Geochimica et Cosmochimica Acta, 63, 489-508. DOI: 10.1016/S0016-7037(99)00027-7

Jahn, B.M., Wu, F., Capdevila, R., Martineau, F., Zhao, Z. and Wang, Y.: 2001, Highly evolved juvenile granites with tetrad REE patterns: the Woduhe and Baerzhe granites from the Great Xing'an Mountains in NE China. Lithos, 59, 171-198.

DOI: 10.1016/S0024-4937(01)00066-4

Jorgensen, C.K.: 1970, The "tetrad effect" of Peppard is a variation of the nephelauxetic ratio in the third decimal. Journal of Inorganic and Nuclear Chemistry, $32,3127-3128$

DOI: 10.1016/0009-2541(93)90102-O

Kamineni D.C. and Efthekhar-Nezad, J.: 1977, Mineralogy of the Permian laterite of Northwestern Iran. Tschermaks Mineralogische und Petrographische Mitteilungen, 24, 195-204. DOI: $10.1007 / \mathrm{BF} 01081127$

Kawabe, I., Ohta, A., Ishii, S., Tokumura, M. and Miyauchi, K.: 1999, REE partitioning between Fe-Mn oxyhydroxide precipitates and weakly acid $\mathrm{NaCl}$ solutions: Convex tetrad effect and fractionation of $\mathrm{Y}$ and Sc from heavy lanthanides. Geochemical Journal, 33, 167-180. DOI: 10.2343 /geochemj.33.167

Kawabe, I.: 1995, Tetrad effects and fine structures of REE abundance patterns of granitic and rhyolitic rocks: ICP-AES determinations of REE and Y in eight GSJ reference rocks. Geochemical Journal, 29, 213-230. DOI: $10.2343 /$ geochemj.29.213

Kawabe, I.: 1996, Convex tetrad effect variations in REE abundances of "North American shale composite" and "Post -Archean Australian average shale. Geochemical Journal, 30, 149-153.

Klinkhammer, G., Elderfield, H. and Hudson, A.: 1983, Rare earth elements in seawater near hydrothermal vents. Nature, 305, 185-188. DOI: 10.1038/305185a0

Koschinsky, A., Stascheit, A., Bau, M. and Halbach, P.: 1997, Effects of phosphatization on the geochemical and mineralogical composition of marine ferromanganese crusts. Geochimica et Cosmochimica Acta, 61, 4079-4094. DOI: $10.1016 / \mathrm{S} 0016-7037(97) 00231-7$

Kraemer, D., Tepe, N., Pourret, O. and Bau, M.: 2016, Negative cerium anomalies in manganese (hydr)oxide precipitates due to cerium oxidation in the presence of dissolved siderophores. Geochimica et Cosmochimica Acta, 196, 197-208. DOI: 10.1016/j.gca.2016.09.018

Lee, S.G., Masuda, A. and Kim, S.H.: 1994, An early Proterozoic leuco-granitic gneiss with the REE tetrad phenomenon. Chemical Geology, 114, 59-67. DOI: 10.1016/0009-2541(94)90041-8

Lee, S.G., Asahara, Y., Tanaka, T., Lee, S.R. and Lee, T.: 2013, Geochemical significance of the Rb-Sr, La-Ce and Sm-Nd isotope systems in A-type rocks with REE tetrad patterns and negative Eu and $\mathrm{Ce}$ anomalies: The Cretaceous Muamsa and Weolaksan granites, South Korea. Chemie der Erde, 73, 75-88.

DOI: 10.1016/j.chemer.2012.11.008

Liu, Y.G., Miah, M.R.U. and Schmitt, R.A.: 1988, Cerium: a chemical tracer for paleooceanic redox conditions. Geochimica et Cosmochimica Acta, 52, 1361-1371. DOI: 10.1016/0016-7037(88)90207-4

Lottermoser, B.G.: 1992, Rare earth elements and hydrothermal ore formation processes. Ore Geology Reviews, 7, 25-41. DOI: 10.1016/0169-1368(92)90017-F

Lv, Z.H., Zhang, H. and Tang, Y.: 2018, Lanthanide tetrads with implications for liquid immiscibility in an evolving magmatic-hydrothermal system: Evidence from rare earth elements in zircon from the No. 112 pegmatite, Kelumute, Chinese Altai. Journal of Asian Earth Sciences, 312-313, 258-273. DOI: $10.1016 /$ j.jseaes.2018.05.031

Madhavaraju, J. and Gonzalez-Leon, C.M.: 2012, Depositional conditions and source of rare earth elements in carbonate strata of the Aptian-Albian Mural Formation, Pitaycachi section, northeastern Sonora, Mexico. Revista Mexicana de Ciencias Geologicas, 29, 478-491.

Madhavaraju, J. and Lee, Y.: 2009, Geochemistry of the Dalmiapuram Formation of the Uttatur Group (Early Cretaceous), Cauvery basin, southeastern India: implications on provenance and paleo-redox conditions. Revista Mexicana de Ciencias Geologicas, 26, 380-394.

Madhavaraju, J. and Ramasamy, S.: 1999, Rare earth elements in limestones of Kallankurichchi Formation of Ariyalur Group, Tiruchirapalli Cretaceous, Tamil Nadu. Journal of the Geological Society of India, 54, 291-301.

Madhavaraju, J., Gonzalez-Leon, C.M., Lee, Y.I., Armstrong-Altrin, J.S. and Reyes-Campero, L.M.: 2010, Geochemistry of the Mural Formation (AptianAlbian) of the Bisbee Group, Northern Sonora, Mexico. Cretaceous Research, 31, 400-414. DOI: $10.1016 /$ j.cretres.2010.05.006

Madhavaraju, J., Kolosov, I., Buhlakb, D., ArmstrongAltrinc, J.S., Ramasamya, S. and Mohan, S.P.: 2004, Carbon and Oxygen Isotopic Signatures in AlbianDanian Limestones of Cauvery Basin, Southeastern India. Gondwana Research, 7, 519-529. DOI: 10.1016/S1342-937X(05)70802-9

Madhavaraju, J., Lee, Y.I., Scott, R.W., Gonzalez-Leon, C.M., Jenkyns, H.C., Saucedo-Samaniego, J.C. and Ramasamy, S.: 2018, High-resolution carbonate isotopic study of the Mural Formation (Cerro Pimas section), Sonora, México: Implications for early Albian oceanic anoxic events. Journal of South American Earth Sciences, 82, 329-345. DOI: $10.1016 /$ j.jsames.2017.10.019

Madhavaraju, J., Loser, H., Lee, Y.I., Lozano Santacruz, R. and Pi-Puig, T.: 2016, Geochemistry of Lower Cretaceous limestones of the Alisitos Formation, Baja California, Mexico: Implications for REE source and paleo-redox conditions. Journal of South American Earth Sciences, 66, 149-165. DOI: 10.1016/j.jsames.2015.11.013

Madhavaraju, J., Loser, H.,Scott, R.W., Sandeep, S., Sial, A.N. and Ramasamy, S.: 2017, Petrography, geochemistry and stable isotopes of carbonate rocks, Lower Cretaceous Alisitos Formation, Los Torotes section, Baja California, Mexico. Revista Mexicana 
Ciencias Geologicas, 34, 63-77.

DOI: $10.22201 /$ cgeo.20072902e.2017.2.458

Masuda A., Kawakami O., Dohmoto Y. and Takenaka T.: 1987, Lanthanide tetrad effects in nature: Two mutually opposite types $\mathrm{W}$ and $\mathrm{M}$. Geochemical Journal, 21, 119-124. DOI: $10.2343 /$ geochemj.21.119

Masuda, A., Matsuda, N., Minami, M. and Yamamoto, H.: 1994, Approximate estimation of the degree of lanthanide tetrad effect from precise but partially void data measured by isotope dilution and an electron configuration model to explain the tetrad phenomenon. Proceedings of the Japan Academy, 70 B, 169-174. DOI: 10.2183/pjab.70.169

McLennan, S.M.: 1994, Rare earth element geochemistry and the "tetrad" effect. Geochimica et Cosmochimica Acta, 58, 2025-2033.

DOI: $10.1016 / 0016-7037(94) 90282-8$

Minami, M., Masuda, A., Takahashi, K., Adachi, M. and Shimizu, H.: 1998, Y-Ho fractionation and lanthanide tetrad effect observed in cherts. Geochemical Journal, 32, 405-419. DOI: 10.2343/geochemj.32.405

Minuzzi, O.R.R., Neto, A.C.B., Formoso, M.L.L., Andrade, S., Janasi, V.A. and Flores, J.A.: 2008, Rare earth element and yttrium geochemistry applied to the genetic study of cryolite ore at the Pitinga Mine (Amazon, Brazil). Anais da Academia Brasileira de Ciências, 80, 719-733.

DOI: $10.1590 / \mathrm{S} 0001-37652008000400012$

Möller, P. and Bau, M.: 1993, Rare-earth patterns with positive cerium anomaly in alkaline waters from Lake Van, Turkey. Earth and Planetary Science Letters, 117, 671-676. DOI: 10.1016/0012-821X(93)90110-U

Möller, P., Bau, M., Dulski, P. and Lüders, V.: 1998, REE and $\mathrm{Y}$ fractionation in fluorite and their bearing on fluorite formation. Proceedings of the 9th Quadrennial IAGOD Symp., Schweizerbart, Stuttgart, 575-592.

Mondillo, N., Boni, M., Balassone, G., Spoleto, S., Stellato, F., Marino, A., Santoro, L. and Spratt, J.: 2015, Rare earth elements (REE) Minerals in the Silius fluorite vein system (Sardinia, Italy). Ore Geology Reviews, 74, 211-224. DOI: 10.1016/j.oregeorev.2015.11.016

Monecke, T., Dulski, P. and Kempe, U.: 2007, Origin of convex tetrads in rare earth element patterns of hydrothermally altered siliceous igneous rocks from the Zinnwald Sn-W deposit, Germany. Geochimica et Cosmochimica Acta, 71, 335-353.

DOI: $10.1016 /$ j.gca.2006.09.010

Monecke, T., Kempe, U., Monecke, J., Sala, M. and Wolf, D.: 2002, Tetrad effect in rare earth element distribution patterns: a method of quantification with application to rock and mineral samples from graniterelated rare metal deposits. Geochimica et Cosmochimica Acta, 66, 1185-1196.

DOI: 10.1016/S0016-7037(01)00849-3

Murphy, K. and Dymond, J.: 1984, Rare earth element fluxes and geochemical budget in the eastern equatorial Pacific. Nature, 307, 444-447. DOI: $10.1038 / 307444 a 0$

Murray, R.W., Ten Brink, M.R.B., Gerlach, D.C., Russ, G.P. and Jones, D.L.: 1991, Rare earth, major and trace elements in chert from the Franciscan complex and Monterey Group, California: Assessing REE sources to fine grained marine sediments. Geochim et Cosmochim Acta, 55, 1875-1895. DOI: 10.1016/0016-7037(91)90030-9
Nabavi, M.: 1976, A preface for geology of Iran. Geological Survey of Iran Publication, 105 pp., (in Persian).

Nagarajan, R., Madhavaraju, J., Armstrong-Altrin, J.S. and Nagendra, R.: 2011, Geochemistry of Neoproterozoic limestones of the Shahabad Formation, Bhima Basin, Karnataka, southern India. Geosciences Journal, 15, 9-25. DOI: 10.1007/s12303-011-0005-0

Nardi, L.V.S., Formoso, M.L.L., Jarvis, K., Oliveira, L., Bastos Neto A.C. and Fontana, E.: 2012, REE, Y, Nb, $\mathrm{U}$, and Th contents and tetrad effect in zircon from a magmatic-hydrothermal F-rich system of Sn-rare metalecryolite mineralized granites from the Pitinga Mine, Amazonia, Brazil. Journal of South American Earth Sciences, 33, 34-42.

DOI: $10.1016 /$ j.jsames.2011.07.004

Nothdurft L.D., Webb G.E. and Kamber, B.S.: 2004, Rare earth element geochemistry of Late Devonian reefal carbonates, Canning Basin, Western Australia: Confirmation of a seawater REE proxy in ancient limestone. Geochimica et Cosmochim Acta, 68, 263283. DOI: $10.1016 / \mathrm{S} 0016-7037(03) 00422-8$

Nugent, L.J.: 1970, Theory of the tetrad effect in the lanthanide (III) and actinide (III) series. Journal of Inorganic and Nuclear Chemistry, 32, 3485-3491. DOI: 10.1016/0022-1902(70)80157-9

Olivier, N. and Boyet, M.: 2006, Rare earth and trace elements of microbialites in Upper Jurassic coral- and sponge-microbialite reefs. Chemical Geology, 230, 105-123. DOI: 10.1016/j.chemgeo.2005.12.002

Pan, Y.M.: 1997, Controls on the fractionation of isovalent trace elements in magmatic and aqueous systems: evidence from $\mathrm{Y} / \mathrm{Ho}, \mathrm{Zr} / \mathrm{Hf}$ and lanthanide tetrad effect- a discussion of the article by M. Bau (1996). Contributions to Mineralogy and Petrology, 128, 405408. DOI: $10.1007 / \mathrm{s} 004100050$

Peppard, D.F., Mason, G.W. and Lewey, S.: 1969, A tetrad effect in the liquid - liquid extraction ordering of lanthanide (III). Journal of Inorganic and Nuclear Chemistry, 31, 2271-2272. DOI: $10.1016 / 0022-1902(69) 90044-X$

Peretyazhko, I.S. and Savina, E.A.: 2010, Tetrad effects in the rare earth element patterns of granitoid rocks as an indicator of fluoride silicate liquid immiscibility in magmatic systems. Petrology, 18, 514-543. DOI: 10.1134/S086959111005005X

Qiu, Z., Wang, Q.C. and Yan, D.T.: 2013, Geochemistry of the Middle to Late Permian limestones from the marginal zone of an isolated platform (Laibin, South China). Science China Earth Sciences, 56, 1688-1700. DOI: $10.1007 / \mathrm{s} 11430-013-4620-7$

Rezaei Azizi, M., Abedini, A., Alipour, S., Niroomand, S., Sasmaz, A. and Talaei, B.: 2017, Rare earth element geochemistry and tetrad effects in fluorites: A case study from the Qahr-Abad deposit, Iran. Neues Jahrbuch für Geologie und Paläontologie, 383, 255273. DOI: $10.1127 /$ njgpa/2017/0639

Rossi, J.N., Toselli, A.J., Basei, M.A., Sial, A.N. and Baez, M.: 2011, Geochemical indicators of metalliferous fertility in the Carboniferous San Blas pluton, Sierra de Velasco, Argentina. Geological Society, London, Special Publications, 350, 175-186.

DOI: $10.1144 / \mathrm{SP} 350.10$

Shannon, R.D.: 1976, Revised effective ionic radii and systematic studies of interatomic distances in halides and chalcogenides. Acta Crystallographica B25, 925946. DOI: $10.1107 / \mathrm{S} 0567739476001551$ 
Sherrell, R.M., Field, M.P. and Ravizza, G.: 1999, Uptake and fractionation of rare earth elements on hydrothermal plume particles at $945^{\prime} \mathrm{N}$, East Pacific Rise. Geochimica et Cosmochimica Acta, 63, 1709_ 1722.

Shields, G.A. and Webb, G.E.: 2004, Has the REE composition of seawater changed over geological time? Chemical Geology, 204, 103-107. DOI: $10.1016 /$ j.chemgeo.2003.09.010

Spandler, C. and Morris, C.: 2016, Geology and genesis of the Toongi rare metal ( $\mathrm{Zr}, \mathrm{Hf}, \mathrm{Nb}, \mathrm{Ta}, \mathrm{Y}$ and $\mathrm{REE})$ deposit, NSW, Australia, and implications for rare metal mineralization in peralkaline igneous rocks. Contributions to Mineralogy and Petrology, 171, 104. DOI: $10.1007 / \mathrm{s} 00410-016-1316-\mathrm{y}$

Takahashi, Y., Yoshida, H., Sato, N., Hama, K., Yusa, Y. and Shimizu, H.: 2002, W- and M-type tetrad effects in REE patterns for water-rock systems in the Tono uranium deposit, central Japan. Chemical Geology, 184, 311-335. DOI: 10.1016/S0009-2541(01)00388-6

Tang, H.S., Chen, Y.J., Santosh, M., Zhong, H. and Yange, T.: 2013, REE geochemistry of carbonates from the Guanmenshan Formation, Liaohe Group, NE SinoKorean Craton: Implications for seawater compositional change during the Great Oxidation Event. Precambrian Research, 227, 316-336. DOI: $10.1016 /$ j.precamres.2012.02.005

Taylor, Y. and McLennan, S.M.: 1985, The Continental Crust: Its Composition and Evolution. 1st ed. Oxford, UK: Blackwell.

Webb, G.E. and Kamber, B.S.: 2000, Rare earth elements in Holocene reefal microbialites: A new shallow seawater proxy. Geochimica et Cosmochimica Acta, 64, 1557-1565. DOI: 10.1016/S0016-7037(99)00400-7

Wu, C.Z., Liu, S.H., Gu, L.X., Zhang, Z.Z. and Lei, R.X.: 2011, Formation mechanism of the lanthanide tetrad effect for a topaz and amazonite-bearing leucogranite pluton in eastern Xinjiang, NW China. Journal of Asian Earth Sciences, 42, 903-916. DOI: $10.1016 /$ j.jseaes.2010.09.011

Yang, Z.Y., Wang, Q., Zhang C., Dan, W., Zhang, X.Z., Qi, Y., Xia, X.P. and Zhao, Z.H.: 2018, Rare earth element tetrad effect and negative $\mathrm{Ce}$ anomalies of the granite porphyries in southern Qiangtang Terrane, central Tibet: New insights into the genesis of highly evolved granites. Lithos 312-313, 258-273. DOI: $10.1016 /$ j.lithos.2018.04.018

Yasnygina, T.A. and Rasskazov, S.V.: 2008, Tetrad effect in rare earth element distribution patterns: Evidence from the Paleozoic Granitoids of the Oka Zone, Eastern Sayan. Geochemistry International, 46, 814-825. DOI: $10.1134 / \mathrm{S} 0016702908080065$

Yurimoto, H., Duke, E.F., Papike, J.J. and Shearer, C.K.: 1990, Are discontinuous chondrite-normalized REE patterns in pegmatitic granite systems the results of monazite fractionation? Geochimica et Cosmochimica Acta, 54, 2141-2145.

DOI: 10.1016/0016-7037(90)90277-R 